\title{
10. Orhan Pamuk'un Masumiyet Müzesi romanını kronotop kavramı çerçevesinde okuma
}

Hatice YILDIZ1

APA: Yıldız, H. (2021). Orhan Pamuk'un Masumiyet Müzesi romanını kronotop kavramı çerçevesinde okuma. RumeliDE Dil ve Edebiyat Araştırmaları Dergisi, (Ö9), 114-136. DOI: 10.29000/rumelide. 983502.

Öz

Kurmaca metnin temel unsurlarından olan zaman ve mekân edebiyat araştırmacıları için ilgi çekici başlıklardır. Ayrı ayrı incelemelere konu olan bu iki kurmaca unsuruna farklı bir bakış açısı geliştiren Mikhail Bakhtin ise mekân ve zamanın birbiriyle ilişkili olduğu düşüncesinden hareket ederek "kronotop” (zaman-mekân) kavramını kullanır. Einstein'ın “Görelilik Teorisi”nden hareketle ortaya çıkan "kronotop" kavramı Yunanca "kronos" (zaman) ve "topos" (yer) kelimelerinin birleşiminden meydana gelir. Bakhtin ise bu kavramı kurmaca metinde zaman ve mekânın birlikteliğini belirtmek için kullanır. Onun tespit ettiği ev, yol, şato gibi kronotoplar bir romanın temel dinamiklerini oluşturur ve soyut bir kavram olan zamanın mekân aracılığıyla somutlaştırılmasını sağlar. Buradan hareketle bu çalışmada son dönem Türk romancllığının önde gelen isimlerinden olan Orhan Pamuk'un Masumiyet Müzesi isimli romanı Bakhtin'in "kronotop" kavramı çerçevesinde incelenecektir. Söz konusu roman bir așk teması etrafında bireylerin ve toplumun yaşadığı değișimi ve dönüșümü ele alır. Arka planında İstanbul'un yer aldığı bu aşk hikâyesinde mekân ve zaman ilişkisinin çarpıcı bir şekilde kurgulandığı görülür. Bu bakımdan romanın da ismi olan "Masumiyet Müzesi" başta olmak üzere metinde sunulan zaman ve mekân unsurlarının olay örgüsünün merkezinde yer aldığı anlaşılır. Roman kişilerinin düşünce ve duygu dünyasını yansıtan, hayatlarını değiștiren, birbirleriyle ilişkilerini belirleyen ve benliklerini yeniden kurgulamalarını sağlayan ev, yol, kapı, eşik, salon gibi kronotoplar metnin anlamına derinlik katar.

Anahtar kelimeler: Modern Türk edebiyatı, Mikhail Bahtin, kronotop, Orhan Pamuk, Masumiyet Müzesi

\section{Reading Orhan Pamuk's novel of Museum of Innocence within the perspective of the chronotope concept}

\begin{abstract}
Time and space, which are the basic elements of fictional text, are interesting topics for literary researchers. Mikhail Bakhtin, who developed a different perspective on these two fictional elements, which are the subject of separate studies, uses the concept of "chronotope" (time-space) based on the idea that space and time are related to each other. The concept of "chronotope", which emerged from Einstein's "Theory of Relativity", consists of the combination of the Greek words "kronos" (time) and "topos" (place). Bakhtin, on the other hand, uses this concept to indicate the coexistence of time and space in the fictional text. Chronotopes such as house, road and castle that he identified form the basic dynamics of a novel and enable time, which is an abstract concept, to be embodied through space. From this point of view, in this study, Orhan Pamuk's novel, The Museum of Innocence, who is one of the leading names in recent Turkish novelism, will be examined based on Bakhtin's concept of "chronotope". The novel in question deals with the change and transformation of individuals and society around a love
\end{abstract}

Dr. Arș. Gör., Ankara Hacı Bayram Veli Üniversitesi, Edebiyat Fakültesi, Türk Dili ve Edebiyatı, Yeni Türk Edebiyatı (Ankara, Türkiye), hatice.yildiz@hbv.edu.tr, ORCID ID: 0000-0001-6494-3276 [Araştırma makalesi, Makale kayıt tarihi: 26.07.2021kabul tarihi: 20.08.2021; DOI: 10.29000/rumelide.983502]

Adres | Address

RumeliDE Dil ve Edebiyat Araştırmaları Dergisi Osmanağa Mahallesi, Mürver Çiçeği Sokak, No:14/8 Kadıköy - ISTANBUL / TÜRKIYE 34714 e-posta: editor@rumelide.com tel: +90 $5057958124,+902167730616$

RumeliDE Journal of Language and Literature Studies

Osmanağa Mahallesi, Mürver Çiçeği Sokak, No:14/8

Kadıköy - ISTANBUL / TURKEY 34714

e-mail: editor@rumelide.com,

phone: +90 5057958124 , +90 2167730616 
theme. In this love story with Istanbul in the background, it is seen that the relationship between space and time is constructed in a striking way. In this respect, it is understood that the time and space elements presented in the text, especially the "Museum of Innocence", which is also the name of the novel, are at the center of the plot. Chronotopes such as house, road, door, threshold, hall, which reflect the thoughts and feelings of the characters in the novel, change their lives, determine their relations with each other and enable them to reconstruct their selves, add depth to the meaning of the text.

Keywords: Modern Turkish literature, Mikhail Bahtin, chronotope, Orhan Pamuk, Museum of Innocence

\title{
Giriş
}

Zaman ve mekân, kurmaca metinlerin olmazsa olmaz iki unsuru olarak araştırmacıların dikkatini çeker. Modern romanın gelişmesine bağlı olarak mekân, olay örgüsü için bir dekor olmanın; zaman ise basit bir takvim meselesi sayılmanın ötesine geçer. Zamana ve mekâna ilişkin tasvirler, roman kişilerinin toplumsal ve psikolojik bir derinlik içinde ele alınmasını sağlar.

Wellek\&Warren'ın belirttiği gibi dil içinde konumlanan roman sanatı, resim veya heykel gibi mekâna bağlı sanatlardan farklı olarak "zamana bağlı bir sanat" olarak değerlendirilir (1983: 294). Zamanın insan hayatına getirdiği nesnel ölçütler sebebiyle kurgu oluşuna dikkat çeken Jale Parla da anlatının ve zamanın özdeşliklerine işaret eder:

\begin{abstract}
"Zaman zaten bir kurgudur. Anlatı da öyle. Baştan başlarken, sondan başlayıp başa dönerken, ortadan başlayıp başa dönüşlerle sona yaklaşırken, sonu açık bırakırken, ileri geri atlayan iç monolog ya da bilinçakışıyla ilerlerken, istençdışı anımsanan büyülü anlar belleğin saatinde biçimlenirken, yitik zamanda gömülü öykülerin peşinden koşarken, büyülü bir dağda zamanı durdurmaya çalışır ya da Londra'nın göbeğindeki saat kulesinin çanlarına meydan okurken, mitik zamanın canlanışlarında insanlığın korkulu düş ve arzuları başkaldırırken, bilinçdışı sahneyi ele geçirip kişiyi suçtan cezaya, acıdan intikama, öfkeden teslimiyete savururken, anlatı zamandır" (2012: 231-232)
\end{abstract}

Olayların belirli bir kronolojik düzenlemeye göre aktarılması demek olan hikâyede zaman unsurunun kurucu bir nitelik taşıdığı ortadadır. Bu bakımdan her anlatı bir zaman kaydıyla sınırlıdır (Tekin, 2001: 122). Vaka zamanı, anlatma zamanı veya okuma zamanı bir anlatının zamanla ilişkili yönlerini ortaya koyan kavramlardır.

Mekân ise "nesnelerin ve karakterlerin yerleştirildiği ortamdır; daha net söylemek gerekirse, karakterlerin içinde yaşadığı ve hareket ettiği çevredir” (Jahn, 2012: 107). Bütün kurmaca metinler, belirsiz bile olsa bir mekânda gerçekleşen olayları anlatır. Bununla birlikte mekânın yegâne işlevi bu değildir. Mekân, kurmaca dünyasına ait bütün unsurları anlaşılır kıldığı gibi, roman kişilerinin iç ve dış gerçekliğinin yansıtılmasını da sağlar (Tekin, 2001: 142). Mekân unsuru, romanın olay örgüsü ve şahıs kadrosuyla sıkı bir ilişki içindedir ve "ister gerçek, ister hayalî olsun, mekân, aksiyona veya zamanın akışına bağlı olarak, kahramanlarla sıkı sıkıya bağlı ve kaynaşmış durumdadır” (Bourneur ve Quellet, 1989: 91). Mekânın anlatı kişileriyle kurduğu ilişkinin derinliği ve karmaşıklığı onu kimi zaman romanın bir figürü hâline de getirebilir: "bazı eserlerde, şahıs kadrosunu teşkil eden fertlerden biriyle mekan arasında varlığı müşahade edilen çok yönlü alış veriş, mekanı vakanın kahramanlarından biri haline getirir. Denilebilir ki, böylece mekan şahıslaşır” (Aktaş, 1991: 145-146).

Daha önce de ifade edildiği gibi bir anlatıda olaylar belirli bir zaman düzleminde gerçekleşir. Bu olayların gerçekleştiği mekânlar ise "sabit bir 'yer' ya da 'dekor' olmanın ötesindedir. İklim koşullarının yanısıra manzaraları da içerir, bahçe ve odaların yanısıra şehirleri de içerir; esasında mekânsal olarak

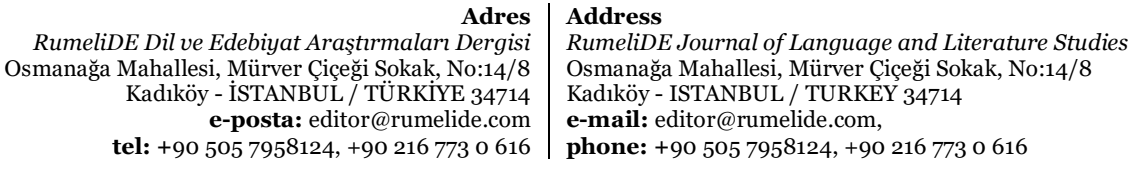


konumlandırılmış nesnelerin ve kişilerin tamamını içerir" (Jahn, 2012: 107). Buradan hareketle bir romandaki zaman ve mekân unsurlarının karşılıklı bir ilişki içinde olduğunu söylemek mümkündür. Seymour Chatman'ın ifadesiyle: "Öykü zamanı olayları içerdiği gibi öykü uzamı da varlıkları içerir. Olaylar uzamsal değildir ancak uzamda meydana gelirler. Uzamsal olan, olayları gerçekleştiren ya da onların etkisi altında kalan varlıklardır" (2008: 89).

Zaman akıp giderken, varlık onu gözenekleri arasında hapsetmek ister. Zamanın varlıkla olan ilișkisi mekânda sabitlenir: "Mekân, peteklerinin binlerce gözünde, zamanı sıkıștırılmış olarak tutar. Mekân bu ișe yarar" (Bachelard, 1996: 36). İnsan, belleği aracılığıyla mekânda ve eşyada sıkışan zamanla irtibat kurar. Bellek ise romanda "nesneyi etkileyen ve dönüştüren yaratıcı bir güç olarak" belirir (Lukacs, 2003: 130) Zira romanın tüm içsel hareketi, geçip giden "zamanın gücüne karşı girilen bir mücadeleden başka bir şey" değildir (Lukacs, 2003: 126). Bu sebeple zaman ve mekânın bir romandaki atmosferin yaratılması, kişilerin çizimi ve olayların yansıtılması gibi işlevlerini bir arada değerlendirmek yerinde olur.

Klasik metin incelemelerinde ayrı başlıklar altında ele alınan bu iki roman unsurunu birlikte düşünmek gerektiğini ortaya koyan isim ise Mihail Bahtin olmuştur. Bahtin'e göre zaman ve mekân birbiriyle bağlantılıdır:

\begin{abstract}
"Edebiyatta ve bizzat sanatta, zamansal ve uzamsal belirlenimler birbirinden ayrilamaz ve daima duyguların ve değerlerin izini taşır. Elbette, soyut düşünce, zaman ve uzamı ayrı kendilikler olarak kavrayıp onlara iliştirilen duygular ve değerlerden ayrı şeyler olarak algılayabilir. Ama (elbette düşünce içeren ama soyut düşünce içermeyen) canlı sanatsal algılama böylesi ayırmalar yapmaz ve bu tür bir parçalamaya müsamaha göstermez. Zaman-uzamı eksiksiz bütünlüğünde ve tamlığında kavrar. Sanat ve edebiyat, çeşitli derece ve kapsamlarda zaman-uzamsal değerlerle doludur" (2014: 296)
\end{abstract}

Bahtin, "Romanda Zaman ve Kronotop Biçimlerine İliş̧in Sonuç Niteliğinde Kanılar" başlıklı yazısında zaman ve mekânın birbirinden ayrılamazlığına dikkat çeker ve kurmaca metnin "biçimsel olarak kurucu kategorisi" olduğunu ifade ettiği zaman-mekânı "kronotop" kavramıyla karşılar (2014: 296). Kronotop, Yunanca "kronos" (zaman) ve "topos" (yer) kelimelerinin bir araya gelmesiyle oluşur. Kelime Einstein'ın Görelilik Teorisi çerçevesinde, matematik alanında kullanılmaktadır. Bununla birlikte Bahtin, bu kelimeyi edebiyat eleștirisinde kullanmak üzere "eğretileme" olarak alır (2014: 296).

Kronotoplar (zaman-uzam/zaman-mekân), bir anlatının temel dinamiğini oluşturur. Soyut bir kavram olan zaman, mekânla ilişkilendirildiği surette somut bir görünüm elde ederken mekân da zamanın varlığıyla derinlik kazanır. Sibel Irzık'ın ifadeleriyle:

\begin{abstract}
"Kronotop, zamanla mekân arasın da çeşitli toplumsal deneyimler aracılığıyla farklı biçimlerde kurulan içsel bağların edebiyattaki özgül görünümlerinin adıdır. Bu anlamda edebiyatla toplum, biçimle ideoloji arasında bir kesişme noktası daha oluşturur. Edebiyatta kronotop aracılığılla zaman ete kemiğe bürünür; mekân, yine aynı yolla zaman ve tarih tarafından anlamlandırılır" (Irzık, 2014: 29).
\end{abstract}

Kronotoplar, Bahtin'e göre "anlatıyı biçimlendiren anlam" olarak romanın merkezinde yer alırlar. Ona göre "zaman-uzam, anlatı düğümlerinin bağlandığı ve birleștiği yerdir” (2014: 303). Temsil etme kabiliyetleriyle kronotoplar, bir romandaki olaylara hayat verir. Anlatının olayları bu sayede somutlaşır ve yine Bahtin'in ifadesiyle "bilgiye dönüşür" (2014: 304).

Kronotoplar, anlatı kişilerini de daha iyi tanıtmaya yardımcı olurlar: "Zaman/uzam, ifadenin olağan figüratif anlamıyla 'karakteri belirginleştirir'; karakterler eylemlerini ve duygularını, nesnelerin toplandığı yer olan zaman/uzama "karşı" uygun bir biçimde ortaya çıkartırlar" (Chatman, 2008: 130).

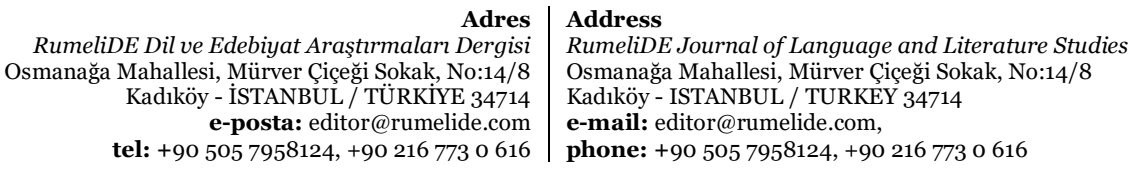


Kronotopun tanımından hareketle anlatı dünyasının tarih ve coğrafyayla kurduğu ilişkiye değinen Nüket Esen de bir eserin toplumsal zemininin kronotoplar sayesinde ortaya konabileceğini ifade eder. Buna göre “[m]etnin dışındaki hayatın, zaman ve mekân tanımı bir metnin kronotopuna sızar. Her kurgu yalnız yapay, üretilmiş değildir; belirli bir zamanda belirli bir kültürdeki zaman ve mekân ilişkisi veriler, belirleyiciler olarak o kurguda yansır... Yani bir metnin zaman/mekân ilișkisi her zaman kendi dışındaki sosyal ve tarihi çevrenin zaman ve mekân ilişkisi bağlamında ele alınmalıdır" (2012a: 72-73). Metnin zaman ve mekânla ve toplumsal olanla kurduğu bu ilişkiye Jale Parla da işaret eder. Parla, Bahtin'in "kronotop kavramıyla "sanat eserini doğuran ve yaşatan atmosferin maddi temellerini belirlemek" amacında olduğunu söyler (2012: 41).

M. Bahtin, söz konusu yazısında bazı kronotoplar belirler ve çeşitli romanlardan örnekler vererek bunları açıklar. Bunlardan ilki "Yol-Karşılaşma Kronotopu"dur. Bu kronotop, taşıdığı duygu değeri açısından oldukça önemlidir: "Karşılaşma kronotopunda, zamansallık öğesi ağır basar ve ayırt edici özelliği duygu ve değerlerin yüksek yoğunluğudur. Karşılaşma ile bağlantılı yol kronotopu ise, daha geniş bir kapsamla ama daha düşük dereceli bir duygu ve değerlendirme yoğunluğuyla karakterize olur" (2014: 296-297).

Yol, bir karşılaşmalar mekânıdır. Toplumun her kesiminden insanın kaynaştığı ve birbirleriyle rastlantısal ilişkiler kurduğu yol-karşılaşma kronotopu aracılığıyla insanlar arası sınıf farklılıkları bir süreliğine ortadan kalkar ve tesadüfler olaylara hükmeder. Bu kronotop hem yeni başlangıçlara hem de sonlara gebedir. Bu bakımdan yolda "zaman adeta uzamla kaynaşarak uzamın içine akar (ve yolu şekillendirir)" (Bahtin, 2014: 297).

Bahtin'in tespit ettiği bir diğer kronotop "Şato Kronotopu”dur ve özellikle Gotik romanların tarihi atmosferini yansıtmaları bakımından önem taşır. Walter Scott gibi isimlerin kaleme aldığı tarihi romanlar için önemli bir zaman-mekân boyutu taşıyan bu kronotopun Türk edebiyatında birebir karşıllı̆ı bulunmamakla birlikte tarihi romanların mekânı olan saraylar, kaleler bu açıdan değerlendirilebilir. Bunun yanında, Ayșe Demir'in de belirttiği üzere, özellikle Türk edebiyatında toplumsal değişimin simgeleri olarak kullanılan konak, yalı, köşk, apartman gibi mekânlar bu kronotop bağlamında ele alınabilir² (2011: 368).

Stendhal ve Balzac'ın romanlarından hareketle Bahtin'in belirlediği bir diğer kronotop ise “Misafir OdasıSalon Kronotopu"dur:

\begin{abstract}
“Anlatısal ve kompozisyona dayalı bir bakış açısından, karşılaşmaların gerçekleştiği yerdir burası (artık 'yolda' veya 'yabancı bir dünyada' bir araya gelmelerde olduğu gibi özgül tesadüfi mahiyetleri vurgulanmamaktadır). Salonlar ve misafir odalarında, entrika ağları örülür, sonuçlar bağlanır; diyalogların gerçekleștiği yerdir bu, kahramanların karakterini, 'fikirlerini' ve 'tutkularını' ifşa ederek, romanda olağanüstü bir önem kazanan bir şey olan diyalogların” (2014: 300).
\end{abstract}

Görünür olma mekânları olan salonlarda dedikodular döner ve toplumsal yapı burada her türlü statü farkını temsil edecek şekilde sergilenir. Güç, zenginlik, ihtişam gibi kavramlar da buralarda somutlaşır. Bireysel ve toplumsal zaman birbiriyle kaynaşır.

“Taşra Kasabası Kronotopu” ise Bahtin'in Madam Bovary'den örnek vermek suretiyle açıkladığı bir diğer kronotoptur. Taşra kasabasındaki zamanın döngüselliğine, yaşamın sıradanlığına ve kendini tekrar edişine dikkat çeken yazarın belirttiği üzere: "Burada hiçbir olaya rastlanmaz, yalnızca kendilerini sürekli yineleyen 'etkinlikler' bulunmaktadır. Zaman burada, ilerlemekte olan hiçbir tarihsel devinim barındırmaz; bunun

Handan İnci Elçi de Türk romanında mekânı incelediği çalışmasında, konak ve apartmanın birer toplumsal gösterge olarak mekân-zaman ilişkisini ortaya koymaları bakımından dikkat çekici olduğunu söyler (2003: 19).

Adres | Address

RumeliDE Dil ve Edebiyat Araşttrmalar Dergisi $\quad$ RumeliDE Journal of Language and Literature Studies

Osmanağa Mahallesi, Mürver Çiçeği Sokak, No:14/8 $\quad$ Osmanağa Mahallesi, Mürver Çiçeği Sokak, No:14/8

Kadıköy - İSTANBUL / TÜRKIYE 34714 Kadıköy - ISTANBUL / TURKEY 34714

e-posta: editor@rumelide.com e-mail: editor@rumelide.com,

tel: +90 505 7958124, +90 2167730616 phone: +90 505 7958124, +90 2167730616 
yerine dar devirlerle ilerler: günün, haftanın, ayın, bir kişinin yaşamının devri. Bir gün bir gündür yalnızca, bir yıl bir ylldır -bir yaşam bir yaşamdır” (2014: 301).

Bahtin, "Eşik Krontopu"nun da duygu ve değer yüklü bir kavram olduğunu ifade eder. Bir "dönüm noktası" ve "kopuş" kronotopu olarak nitelediği eşiğin "yaşamın bir kopuş noktasıyla, krizle, dönüm anıyla, bir yaşamı değiştiren kararla (ya da bir yaşamı değiştirmede başarısızlığa uğrayan kararsızlıkla, eşiğin ötesine adım atma korkusuyla) bağlantılı" olduğunu belirtir (2014: 302). Ona göre eşik gibi, koridor ve merdiven kronotoplarının da insan hayatındaki anlık olmakla birlikte etkisi bir ömür sürecek kararların, değișimlerin, krizlerin mekânı olduğu söylenebilir (2014: 302).

Mihail Bahtin, ilgili yazısında bu kronotoplardan bahsetmekle birlikte sınırsız sayıda kronotopun farklı anlatılar aracllı̆̆ıla tespit edilebileceğini dile getirir. Ona göre bir esere hatta bir yazara özgü yeni kronotoplar bulunabilir, bu kronotoplar birbiriyle karmaşı ilişkiler geliştirebilir (2014: 305-306). Nitekim Bahtin, Dostoyevski'nin eserleri üzerine yaptığı incelemelerde de eşikle birlikte "lobi, koridor, sahanlık, merdiven, merdiven basamakları, merdivene açılan odalar, ön ve arka avluya açılan kapılar ve bunların ötesinde şehir: meydanlar, sokaklar, binaların dış cepheleri, meyhaneler, batakhaneler, köprüler, mezbeleler"den bahsder (2004: 242).

Benzer şekilde araştırmacılar, Gaston Bachelard'ın bellek ve mekân ilişkisini ele aldığı Mekânın Poetikası isimli eserinden hareketle ev-yuva, köșe, dolap-çekmece-sandık gibi kronotoplara da edebi metin çözümlemelerinde yer verir.

Çalışmamızda bir kısmı Bahtin tarafından tespit edilen kronotopların yanı sıra Masumiyet Müzesi ${ }^{3}$ romanının tematik yapısı ve işleyişini etkileyen yeni kronotoplar da başlıklar hâlinde incelenecektir.

\section{Masumiyet Müzesi romanında kronotop}

Masumiyet Müzesi, İstanbul sosyetesine mensup bir adamla fakir bir kızın arasında yaşanan tutkulu aşkı ve bu aşkın bir roman ve bir müze aracılığıyla ebedileștirilmesini anlatır. Kemal Basmacı isimli zengin bir erkeğin uzak akrabası Füsun'la arasında yaşananları ele alan romanın büyük bir bölümü 1975'ten 1984'e kadar geçen sürede, söz konusu aşk etrafında gelişen olaylara odaklanır. Eserin geri kalan kısmında ise Kemal Basmacı'nın, sonraki yirmi yıl içinde, bu aşka adadığı müzesini nasıl kurduğu ve yaşadıklarının nasıl romana dönüștüğü okunur. Masumiyet Müzesi, olay örgüsündeki sağlamlığının yanı sıra mekân ve zaman unsurlarının işlenişi bakımından modern romana yaklaşmakla birlikte, üstkurmaca yapısı ve metinlerarası ilişkiler gibi özellikleriyle de postmodern bir yapı arz eder. Romanın ilk bölümü, kahraman-anlatıcı Kemal Basmacı tarafından hikâye edilir. Kemal, kaybettiği aşkı Füsun'a dair biriktirdiği her şeyi (anıları, eșyaları) tek tek anlatır. Bu açıdan romanın bu kısmı bir deneyim, arayış ve olgunlaşma hikâyesi olarak da okunabilir. Fakat unutmamak gerekir ki "[d]eneyimden önceki haline dönmesi imkânsız olan öznenin, o deneyimi dil aracılığıyla birebir olarak aktarması mümkün değildir. Bu da deneyimlerin aktarılırken bir kurmacaya dönüşmesine yol açar" (Paliçko, 2020: 118). Nitekim Kemal'in bir kurmaca olduğunu ara sıra dile getirdiği hikâyesinin sonlarına doğru, romana yazar-anlatıcı olarak Orhan Pamuk da dâhil olur. Böylece, romanın yazılıș hikâyesine yer verilir ve kurmacanın varlığı da apaçık sergilenir. Bu üstkurmaca tekniğiyle yazar, edebiyat deneyimini eserine taşımıș olur. Orhan Pamuk'un başka romanlarında da başvurduğu bu tutum,

3 Masumiyet Müzesi'nin ilk baskısı 2008'de İletişim Yayınları tarafından gerçekleștirilmiștir. Bu makalede yer alan alıntılar romanın YKY tarafından gerçekleștirilen 4. Baskısına aittir.

Adres $\mid$ Address

RumeliDE Dil ve Edebiyat Araşturmaları Dergisi Osmanağa Mahallesi, Mürver Çiçeği Sokak, No:14/8 Kadıköy - ISTANBUL / TÜRKIYE 34714 e-posta: editor@rumelide.com tel: +90 $5057958124,+902167730616$

RumeliDE Journal of Language and Literature Studies

Osmanağa Mahallesi, Mürver Çiçeği Sokak, No:14/8

Kadıköy - ISTANBUL / TURKEY 34714

e-mail: editor@rumelide.com,

phone: +90 505 7958124, +90 2167730616 
edebiyat deneyiminin hazzını, "yazma eyleminin bilincinde olarak hikâyeler anlatmanın zevkini" taşır (Esen, 2012b: 222).

Romandaki olayların geçtiği Nişantaşı, Çukurcuma gibi semtleriyle İstanbul şehrine, sokaklara ve evlere dair tasvirlerle, buralarda akıp giden yahut durmuş gibi olan zamanı ve toplumsal yapıyı ortaya koyan ifadeler, okuyucunun zihninde zengin çağrışımlara kapı aralar. Söz konusu aşk hikâyesinin oturtulduğu bu detaylı zaman ve mekân çerçevesi, romanı kronotopik bir okumayla değerlendirme imkânı sunar. Romandaki kronotoplar şehir, yol-karşılaşma, ev, eşik, kapı, pencere-balkon, çekmece-dolap-sandık ve müze başlıkları altında incelenebilir.

\title{
1. 1. Bir kronotop olarak şehir: İstanbul
}

Bir İstanbul yazarı olarak tanımlayabileceğimiz Orhan Pamuk'un romanlarının hemen hepsinde İstanbul, az veya çok bilinen yönleriyle, zengin tarihiyle, toplumsal çağrışımlarıyla ve ona kimliğini kazandıran bütün unsurlarıyla sergilenir. Masumiyet Müzesi'nde de Pamuk'un köșe bucak tanıdığı İstanbul, zengin ve fakir semtleriyle, sokaklarıyla, boğazıyla ve roman kahramanı Kemal'in gençlik yıllarını yansıtan tarihi-toplumsal atmosferiyle hayat bulur.

Başta yazarın doğup büyüdüğü semt olan Nişantaşı, sosyete cenazelerinin kaldırıldığı Teşvikiye Camii'yle, Kemal Basmacı ve çevresinden zengin arkadaşlarının yaşadıkları modern aile apartmanlarıyla, lüks mağazalarıyla yer alır romanda. Kahraman-anlatıcı Kemal, bu semtin sokaklarında gezinir. Pamuk'un hatıralarında olduğu gibi Kara Kitap isimli romanında da andığı "Alaaddinin dükkânı", Masumiyet Müzesi kahramanının da uğradığı yerlerdendir. Nişantaşı'yla beraber Kemal'in Boğaz'da gittiği lüks lokantalar, Fuaye, İnci gibi restoran ve pastaneler, onun ve yüksek sosyete mensubu arkadaşlarıyla sıklıkla bir araya geldikleri, karşılaştıkları, yiyip içtikleri ve eğlendikleri mekânlar olarak dikkat çeker. Bunlardan Fuaye, sosyetenin kalbinin attı̆̆ bir yer olarak öne çıkar. Burası Kemal'in en çok bulunduğu restoranlardan biridir ve kurduğu müzede buraya ait hatıralar da yer alır:

\begin{abstract}
"Yıllar sonra resimli yemek listesini, bir ilanını, özel kibritini ve peçetesini arayıp bulduğum ve burada sergilediğim Fuaye, kısa zamanda Beyoğlu, Şişli, Nişantaşı gibi semtlerde yaşayan sınırlı sayıda zenginin (gazetelerin dedikodu sütunlarının alaycı diliyle söylersek "sosyetenin" en çok sevdiği Avrupa tarzı (Fransız taklidi) lokantalarından biri oldu. Müşterilerine bir Avrupa şehrinde oldukları izlenimini altını çok çizmeden vermek isteyen bu lokantalara Ambassador, Majestik, Royal gibi Batılı ve iddialı adlar yerine, Batı'nın kenarında, İstanbul'da olduğumuzu hatırlatan Kulis, Merdiven ve Fuaye gibi adlar verilirdi. Daha sonraki kuşak yeni zenginlerin gösterișli mekânlarda anneannelerinin pișirdiği yemekleri tercih etmeleriyle, gelenek ve gösteriși birleștiren Hanedan, Sultan, Hünkâr, Pașa ve Vezir gibi pek çok yer açıldı ve Fuaye unutulup gitti" (2014: 20).
\end{abstract}

Fuaye gibi lokantalarda dikkati çeken şey ise zamanla değişen siyasi ve toplumsal atmosferden etkilenerek isimlerinin ve müşteri profilinin değişmesi olur.

Kemal, İstanbul'un zengin semtlerinin yanı sıra Fatih, Kocamustafapaşa, Beyoğlu gibi muhitlerde, arka sokaklarda ve Çukurcuma'da birbirinden farklı kökenlerden gelen işçisi, emeklisi, dedikoducu kadınlarıyla mahalle fikrinin henüz kaybolmadığı yerlerde de gezinir. Bu gezintilerinin çoğunu, kaybettiği sevgilisi Füsun'u bulabilmek için gerçekleştirir. Onunla karşlaşabilme ihtimalinin olduğu caddeler, sinemalar Kemal'in çıktığı şehir turunda okurun muhayyilesini de canlandırır:

\footnotetext{
"Ama onu karşımda görüvermek içimde öyle tatlı bir duygu uyandırırdı ki, onun hayaletiyle karşılaşacağım kalabalık yerlere gitmeyi alışkanlık edinmiştim; bu yerleri, sanki kafamın içindeki bir İstanbul haritasına da işaretlemiştim. Füsun sandığım gölgelerin daha çok görüldüğü yerlere gitmek geliyordu hep içimden. Şehir benim için onu hatırlatan bir işaretler âlemi olup çıkmıştı" (2014: 176).
}

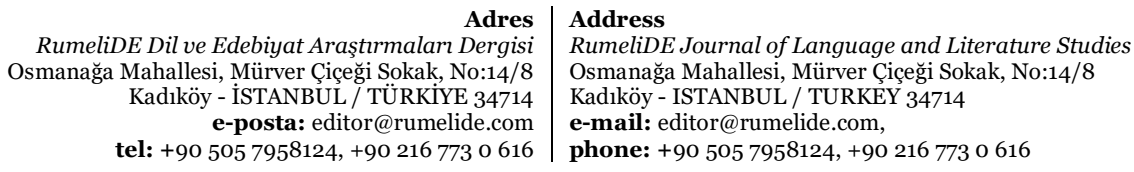


İstanbul, baştanbaşa Kemal'in aşk şehri olmuştur. Füsun'u bulmadan rahat edemeyeceğini anlayan Kemal, şehri karış karış dolaşmaya başlar. Bu gezintileri, yıllar sonra "çok mutlu saatler" olarak hatırlayacaktır:

\begin{abstract}
"Füsun'un hayaleti, Vefa, Zeyrek, Fatih, Kocamustafapaşa gibi ücra ve yoksul mahallelerde karşıma çıkmaya başladığı için Haliç'in öte yakasına geçiyor, şehrin eski mahallelerine gidiyordum. Parke taşı kaplı çukurlu dar sokaklarda tatlı tatlı sallanan arabayı elimde sigara sürerken, bir köşeden Füsun'un hayaleti bir anda karşıma çıkınca, hemen durup park eder ve onun yaşamakta olduğu bu güzel ve yoksul semte derin bir sevgi duyardım. Başörtülü yorgun teyzelerin, mahallenin hayaletlerinin peșine düşmüş yabancıları dikkatle süzen bıçkın delikanlıların ve kahvehanelerde gazete okuyarak pinekleyen işsizlerle ihtiyarların soluk alıp verdiği kömür dumanı kokan bu sokakları, bütün aşkımla kutsardım. İyice uzaktan takip ettiğim herhangi bir gölgenin Füsun'a benzemediğini görünce, mahalleyi hemen terk etmez; hayaleti burada belirdiğine göre, Füsun'un kendisinin de buralarda bir yerde olması gerektiğine kanaat getirerek, sokaklarda aylak aylak sallanırdım. Kedilerin yalandığı meydandaki kör çeşmenin iki yüz yirmi yıllık mermerleriyle birlikte gözün görebildiği bütün düz yüzeylerinin ve duvarlarının, çeşitli sağ ve sol siyasal partilerin, o zamanlar 'fraksiyon' denen grupların sloganlarıvle ölüm tehditleriyle kaplı olmasından hiç huzursuz olmazdım. Az önce Füsun'un buralarda bir yerde olduğuna bütün kalbimle inanmıș olmam, bu sokaklara bir masal ve mutluluk halesi verirdi. Onun hayaletinin gezindiği bu sokaklarda daha çok yürümem, mahalle kahvelerinde çay içip pencereden dışarı bakmam ve onun bu sokaktan geçişini beklemem gerektiğini düşünür; ona ve ailesine yakın olabilmek için onun ve ailesinin yaşadığı gibi yaşamam gerektiğini aklımdan geçirirdim" (2014: 218-219).
\end{abstract}

Kemal'in İstanbul'un yoksul ve ücra semtlerinde dolaşırken karşılaştığı tarihi bir yapı, bina veya çeşmenin 70’lerin hareketli siyasi hayatını gösteren sloganlarla kaplı olması da dikkat çekicidir. Tarihin şimdiyle, zevk-i selimin vandallıkla bir araya geldiği bu yerlerin anlatımı, devri belirleyen ürkütücü atmosfere küçük bir dikkat olarak görülebilir. Zira burjuva dünyasına mensup pek çok kişi gibi Kemal için de bu siyasi çatışmalar bir anlam ifade etmemektedir. Füsun'u ararken artık ayağını kestiği zengin semtlerin bu kavgalardan haberi yok gibidir. 80 darbesinin arifesinde, șehrin bu bölgelerinden de duyulmaya başlayan patlamalar veya silah sesleri ise Kemal'i ya da annesini gece karanlığında kısa süreliğine uyandıran hadiselerdir. Kemal hem mensubu olduğu toplumsal sınıf hem de Füsun'a duyduğu aşkın bütün benliğini ele geçirmesi sebebiyle İstanbul sokaklarını karıștıran sağ-sol çatışmalarına ilgi göstermez. Siyaseten bir tarafa bağlanmış da değildir. Yine de faydasız bulduğu bu çatışmalardan korkar, ara sıra bir iç savaş çıkmasından endişe eder. Darbeden sonra ise onu endișelendiren tek șey, sokağa çıkma yasağı başlamadan Füsunların evinden çıkmak zorunda kalması ve Füsun'u görmeye doyamaması olacaktır.

Füsun'u bulduğu tarihten sonra da Kemal'in İstanbul'da Nişantaşı ile Füsunların yaşadığı Çukurcuma'daki evleri arasındaki gidiş gelişleri devam eder. Kendisini terk edip ortadan kaybolan Füsun, bir senaristle evlidir artık. Kemal'le tekrar görüşmek istemesinin sebebi ise kocasının çekmeyi düşündüğü film için para bulmaktır. Füsun'u kaybetmemek için buna razı olan Kemal, 1976'dan 1984'e kadar Füsunların evine ziyaretlerini sürdürürken bir yandan da İstanbul'un renkli bir yüzüyle, Yeşilçam'la tanışır: Sinema dünyasına Füsun'un kocası Feridun aracılığıyla giren Kemal, yeni evli çiftle yazlık sinemalara gidip sıradan insanlarla birlikte Yeşilçam melodramlarını, dönemin yeni şöhretlerinden olan Orhan Gencebay'ın arabesk tadındaki filmlerini seyreder, Pelür Bar gibi sinema emekçilerini ağırlayan mekânlarda dolaşır. Sinema dünyasının aktörleri, aktrisleri ve yapımcllarıyla buralarda bir araya gelir.

Kemal, sadece sevdiği kadına yakın olmak, onu seyredebilmek için Boğaz'daki lokantalarda Feridun ile Füsun'u birçok kez yemeğe götürür. Sevdiğiyle bir araya geldiği böylesi anlardan küçük mutluluklar devşirmeye çalışır: “Bir akşam Yani'nin Yerinde Füsun'un karşısında oturmanın verdiği huzur içimdeki aşk cinlerini yatıştırınca, mutluluğun çok basit ve herkesin bilmesi gereken reçetesini keşfedip kendi kendime mırıldandığımı da hatırlıyorum: Mutluluk, insanın sevdiği kişiye yakın olmasıdır yalnızca. (Ona hemen sahip olmamız gerekmez.)" (2014: 266).

Adres

RumeliDE Dil ve Edebiyat Araştırmaları Dergis Osmanağa Mahallesi, Mürver Çiçeği Sokak, No:14/8 Kadıköy - ISTANBUL / TÜRKIYE 34714 e-posta: editor@rumelide.com tel: +90 $5057958124,+902167730616$
Address

RumeliDE Journal of Language and Literature Studies

Osmanağa Mahallesi, Mürver Çiçeği Sokak, No:14/8

Kadıköy - ISTANBUL / TURKEY 34714

e-mail: editor@rumelide.com,

phone: +90 505 7958124, +90 2167730616 
Bu mutluluk anlarını kaybetmek istemeyen Kemal, ileride oluşturacağı müzesi için, gittiği kimi yerlerden eşyalar toplar:

\begin{abstract}
"Boğaz lokantalarında onun karşısında otururken, daha sonraki günlerde onu özleyince çekeceğim acıları düşünüp masadaki bazı eşyaları onun karşısında oturma mutluluğumu bana hatırlatsınlar ve yalnızlık anlarımda bana güç versinler diye yanıma aldım ve sakladım. Mesela bu küçük teneke kaşı̆̆ı, Yeniköy'deki Aleko'nun Yerinde kocasıyla küçük bir futbol sohbetine daldığımız sırada -ikimizin de Fenerbahçeli olması, yüzeysel bir çatışmaya fırsat vermediği için iyiydi- sıkıldığı için Füsun ağzına sokup uzun uzun oynamıştı. Bu tuzluğu, tam kullanırken pencerenin önünden çok yakınımızdan geçen, pervanesinin dönüşü masamızın üzerindeki şişeleri ve bardakları titreten paslı bir Sovyet gemisine bakarken uzun bir süre elinde tutmuștu" (2014: 266).
\end{abstract}

Kemal, Füsun'u ararken dolaştığı İstanbul'u, 1983 yılının yazından itibaren Füsun'la birlikte dolaşmaya başlar. Bu dönem, onun Füsun'a nihayet kavuşacağını ve aradaki engellerin kalkacağını düşündüğü bir zaman dilimidir. Araba kullanmayı bir güçlülük göstergesi sayan Füsun'la șehrin caddelerinde sürüş denemeleri yapan ve ehliyet sınavı için gerekli yerlere giden Kemal, İstanbul'un başka yüzlerini tanır:

\begin{abstract}
"Birbirimizi yeniden tanır gibi, birlikte İstanbul'u keşfetmekten, şehrin ve Füsunun her gün yeni bir halini görmekten derin hazlar alıyordum. Hastanelerin yoksulluğuna ve düzensizliğine tanık olduğumuzda, doktora bir görünebilmek için sabahın erken saatinde üniversite hastanelerinin kapılarında kuyruk olan ihtiyarların sefaletini gördügümüzde, arka sokaklardaki boş arsalarda belediyeden gizli kaçak kesim yapan telaşlı kasaplarla karşılaştığımızda, hayatın karanlık yanlarının bizi birbirimize yaklaștırdığını hissederdim. Bizim hikâyemizin tuhaf, hatta itici yanı; șehrin ve insanların, sokaklarda yürüdükçe sezdiğimiz karanlık ve korkutucu yanlarıyla karşılaştırıldığında, o kadar da önemli değildi belki. Şehir bize hayatlarımızın sıradan yanını hissettiriyor ve herhangi bir suçluluk duygusuna kapılmadan alçakgönüllü olmayı öğretiyordu. Sokaklarda yürürken, dolmuşta, otobüste, şehrin kalabalığına karışmanın teselli edici gücünü içimde hisseder, vapurda yan koltukta kucağında uyuklayan torunuyla yolculuk eden başörtülü teyzeyle ahbaplığı ilerleten Füsun'a hayranlıkla bakardım" (2014: 446-447).
\end{abstract}

Tanımadığı, bilmediği çevreleri Füsun yanındayken tecrübe etmek ona kendi dertlerinin küçüklüğünü gösterdiği gibi mutluluk duygusuna tevazu içinde karşılamayı ve hayatın acıları karşısında sükûnetinin korumayı öğretir.

Füsun, kocasından ayrılıp Kemal'le evlenmeye karar verdikten sonra ise iki sevgili, Beyoğlu sinemalarında oynatılan filmleri seyretmeye giderler ve hakiki bir çift gibi davranmaya çalışırlar. Kemal'in bütün ümitleri Füsun'un bilerek arabayı ağaca çarpmasının ardından tükenir. Füsun ölür, kendisi de aylarca hem fiziksel hem de ruhsal olarak toparlanamaz. Aradan geçen uzun zamandan ve tedavilerden sonra yeniden İstanbul'da gezinen, arkadaşlarıyla buluşan Kemal, şehrin artık bambaşka bir yere dönüştüğünü acı içinde fark eder: "Bu yeni sokaklar, İstanbul'a her gün bir yenisi eklenen betondan tuhaf mahalleler, hastaneden çıktıktan sonra hemen hissettiğim şeyi, Füsun'un ölümünden sonra İstanbul'un bambaşka bir yere dönüştüğü duygusunu kuvvetlendiriyordu" (2014: 509).

Teselliyi Füsunların evine gidip annesini ziyaret etmekte bulan Kemal, daha sonra yıllarını alacak yolculuklara başlar. Bu yurtdışı yolculuklarında birbirinden farklı temalara sahip küçük ve kişisel müzeleri gezer. Bu müze gezileri, ona Füsun'un hatıralarını olduğu kadar, bu hatıralara sahne olan İstanbul'u da anlatması gerektiğini hissettirir. Yıllar boyunca biriktirdiği ve daha sonra koleksiyonerlerden hatta çöp evlerden topladığı çeşitli eşyalar, kartpostallar, resimler vb. aracılı̆̆ıyla sevdiği kadını ve sevdiği İstanbul'u unutulmaktan korumak ister. Aşkını İstanbul'dan ayrı düşünemeyen Kemal'e göre İstanbul'u, Nişantaşı'nı, Çukurcuma'yı tanımayan biri, onun Füsun'a beslediği duyguları da tam olarak anlayamaz. Bu düşüncelerle çıttığı yolculuklarda kişisel müzeleri ziyaret eden Kemal'in zihninde bir roman yazdırmak ve "Masumiyet Müzesi”ni kurmak fikirleri belirir. Yazar Orhan Pamuk'u söz konusu romanı yazmaya ikna eden Kemal

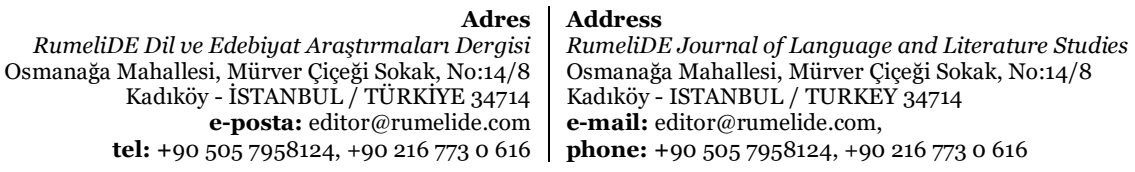


Basmacı'nın anlattığı hikâye "Leyla ile Mecnun gibi, Hüsn ile Aşk gibi, yalnızca âşıkların değil, bütün bir âlemin, yani İstanbul'un hikâyesi”dir (2014: 542).

İstanbul, Masumiyet Müzesi kahramanının yaşadığı ve daimi bir surette etkileşim hâlinde olduğu bir şehirdir. Kapsadığı deniz, boğaz, lokanta, meyhane, otel, bar, hastane, apartman gibi doğal veya insan yapısı unsurlarla zengin bir anlam dünyası oluşturur. İstanbul, roman boyunca sakinlerinin benimsediği birbirinden farklı hayat tarzlarını, toplumsal ve kültürel özellikleri bazen uyumlu, bazen uyumsuz şekilde seslendirilen bir şarkı gibi duyurur. Geçmişin izlerini taşıdığı kadar, anın mührünün de vurulduğu bir şehir olarak İstanbul, Masumiyet Müzesi romanındaki olay örgüsüne zemin teşkil eder, roman kişilerine bir çerçeve çizer ve tarihsellik kazandırır.

\title{
1. 2. Yol-karşılaşma kronotopu
}

Yol kronotopu, uzun veya kısa yolculuklara işaret eder. Bir akışın, hareketin mekânıdır yollar. Masumiyet Müzesi'nin âşı kahramanı Kemal Basmacı da oldukça hareketli bir figürdür. İstanbul semtlerinde yakın çevresiyle görüşür, nişanlısı ve arkadaşlarıyla gezintiler yapar. Ayrıca kaybettiği sevgilisini aramak için de caddeleri ve sokakları arşınlar. Onun yürüyerek veya arabayla kat ettiği yollar, öncelikle kişileri birbirine bağlama işlevi görür. Bununla birlikte, özellikle Füsun'un ortadan kaybolduğu aylarda bir arayış mekânıdır yollar. Kemal, Nişantaşı'nda ve daha sonra İstanbul'un fakir semtlerinde cadde cadde, sokak sokak Füsun'u arar.

Gidiş ve gelişleri bünyesinde barındıran yol kronotopu, kavuşma ve ayrılık çağrışımlarını bir arada bulundurur (Demir, 2011: 304). Masumiyet Müzesi'nin kahramanı Kemal'i Füsun'dan ayıran ve aylarca devam eden bir bekleyişe sürükleyen yollar olduğu gibi Füsun'a kavuşturan yollar da vardır. Bu yollar Nişantaşı'ndan Taksim'e, Beyoğlu'na ve Çukurcuma'ya uzanır. Birbirinden farklı semtler, semtlerin sakinleri Kemal'in gözlerinden sunulur. Böylece toplumun çeşitli kesimlerinden insanlarla yol üzerinde karşılaşılır. Kemal'in gözünden Füsun'un oturduğu Çukurcuma'daki mahalleler oldukça heterojen bir görünüm sunar:

\begin{abstract}
"Mahalle kalabalığı çeşitliydi: Galata'da limanda işçilik yapanlar, Beyoglu'nda ara sokaklarda küçük dükkânları, lokantaları işletenler vegarsonlar, Tophane tarafından yayılarak gelen Çingene aileleri, Tuncelili Alevi Kürt aileleri, bir zamanlar Beyoğlu'nda, BankalarCaddesinde kâtiplik yapan Rum, İtalyan, Levanten ailelerinin fakirdüşmüş çocukları ve torunları, tıpkı onlar gibi İstanbul'u hâlâ bir türlüterk etmeyen son Rum aileleri, depolarda, firınlarda çalışanlar, taksi şoförleri, postacılar, bakkallar ve üniversitelerin yoksul öğrencileri..." (2014: 300).
\end{abstract}

70'lerin sonuna gelindiğinde karşılaşılan kimseler ise daha tehlikeli ve karanlık olur. Çeșitli siyasi fraksiyonlara mensup bu kişiler, sokakların hâkimiyeti için birbiriyle çatışmakta ve yolda gidenleri korkutmaktadırlar:

\begin{abstract}
“1978'de artık bizim mahallede de geceleri bombalar patlıyordu. Tophaneye ve Karaköy tarafına uzanan sokaklar milliyetçilerin, ülkücülerin denetimindeydi ve gazeteler buralardaki kahvelerde pek çok cinayetin planlarının yapıldığını yazardı. Çukurcuma Yokuşu'ndan yukarıya. Cihangire doğru çıkan parke taşı kaplı çarpık çurpuk sokaklarda ise Kürtler, Aleviler, çeşit çeşit sol fraksiyona yakınlık duyan küçük memurlar, işçiler ve öğrenciler yuvalanmıştı. Onlar da silah kullanmayı severdi. ... Keskinlerden çıktığım saatlerde Çukurcuma, Tophane, Cihangir sokakları hiç tekin olmazdı. Arabayla evimize dönerken bile afiş asan, bildiri yapıştıran ya da duvarlara slogan yazan birilerini hep görür, korku içinde bakışırdık" (2014: 371-372).
\end{abstract}

Yol-Karşılaşma kronotopu, bazı anlık karşılaşmalara, tesadüflere açıktır. Füsun'u aradığı aylarda sıklıkla şehri gezen Kemal de bazen ona rastlar gibi olur. Bu çarpıcı rastlantılar, onu derinden sarsar:

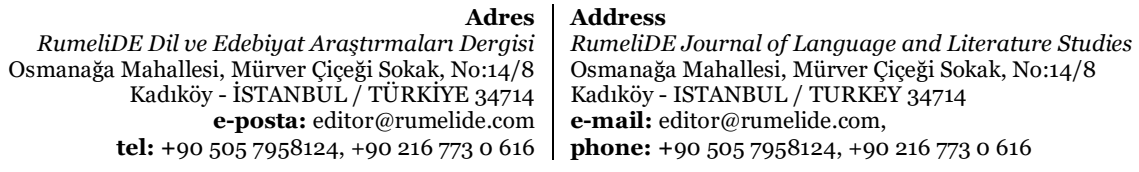


"En sarsıcı ilk karşılaşma, Suadiye'ye taşınmıș olan annemlere Temmuz sonuna doğru bir akşamüstü arabalı vapurla giderken gerçekleşti. Kabataş'tan Üsküdar'a yanaşmakta olan vapurun içindeki diğer sabırsız şoförler gibi, arabamın motorunu çalıştırmıştım ki, yanda yaya yolculara ayrılmış kapıdan çıkarken Füsun'u gördüm. Arabaların inişine ayrılan kapı henüz açılmamıştı, ancak arabadan firlayıp arkasından koşarsam ona yetișebilirdim, ama o zaman da vapurun çıkıșını tıkayacaktım. Yüreğim hırsla çarparken, kendimi dışarı attım. Bütün gücümle ona tam seslenecektim ki, görüş açıma giren belden aşağısının sevgilimin güzelim gövdesinden çok daha kalın ve kaba olduğunu, yüzünün de bambaşka birinin yüzü şekline girdiğini acıyla fark ettim. Acımın bir mutluluk heyecanına dönüştüğü o sekiz-on saniyeyi, ertesi günlerde ağır çekimle hep yeniden yașadım ve onunla böyle karșılașacağımıza içtenlikle inanmaya başladım" (2014: 181).

Füsun'a kavuşma ümidini tazeleyen bu karşılaşma, yanılgının bütün acısına rağmen, tatlı heyecanlar da taşır. Kemal daha sonra buna benzer pek çok hayali karşılaşmalar yaşayacak ve bir gün Füsun'a rast gelebilmek için İstanbul'un fakir semtlerini gezmeye başlayacaktır.

Kemal'in yolda karşılaştığı bir diğer isim de Füsun'un kocası Feridun olur. Füsun'u bulduktan sonra onun evlendiğini ve kendisiyle de menfaati için görüşmeye başladığını öğrenen Kemal, bir daha onu görmeyeceğine kendi kendine söz verir. Fakat evine dönerken yolda karşısına Feridun çıkar. Sarhoşluğun da etkisiyle birden karar değiştiren Kemal, Feridun'a çekmek istediği filmde yardımcı olmak istediğini söyler. Bu teklife Feridun da şaşırır. Kemal'in bu kararının altında Füsun'a duyduğu saplantılı aşkı yatmaktadır. O, Füsun'u görmeden yaşayamayacağını düşünür.

Bir diğer dikkat çekici karşılaşma ise yıllar sonra Milano'da gerçekleşir. Kemal, Bagatti Valsecchi Müzesi'ni gezmek için gittiği bu şehirde 31 yıl önce nişandan ayrıldığı Sibel ve ailesiyle karşılaşır. Karşılaşma, yazar Orhan Pamuk'a Sibel Hanım tarafından anlatılır. Sibel'in, kendi gençliğine çok benzediğini söylediği kızı Gül'ü yolda gören Kemal, şaşkınlık içinde ona "Sibel!" diye seslenir. Eski nişanll, yıllar sonra Milano'da karşılaştığı Kemal'in hâlinin perişanlığından etkilenir. Kemal bu karşılaşmadan bir gün sonra ölür.

Yol kronotopunun yüklendiği bir başka önemli değer ise onun hem bir başlangıç hem de bir bitişin mekânı olabilmesinden kaynaklanır. Masumiyet Müzesi romanında da yolun böyle güçlü bir duygu taşıdığı görülür. Zira kahraman-anlatıcı Kemal Basmacı'nın büyük aşk hikâyesi bir yolda gerçekleșen tesadüfle başladığı gibi, bir yol üzerindeki kazayla da sona erer.

1975 Nisan'ında Kemal ve sevgilisi Sibel, Nişantaşı'nda yürürken Şanzelize Butik'in vitrininde Jenny Colon marka bir çanta görürler ve Sibel çantayı çok beğenir. Ertesi gün o butiğe çantayı almaya giden Kemal, uzak akrabalarından Füsun'un o dükkânda çalıștığını görecek, yıllardır görmediği bu kızın güzelliğine kapılacaktır.

Füsun'la Kemal'in kendi seyrinde ilerleyen aşkları ise düğün öncesi çıktıkları Paris yolculuğu sırasında ebedi ayrılıkla neticelenir. Yıllar boyunca sevdiği kıza kavuşma hayali kuran Kemal, 1984 yılı Ağustos'unda artık boşanmış bir kadın olan Füsun'la evlilik arifesindedir. Kemal, Füsun'la sorunsuz ve mutlu, yeni bir hayata adım attığını düşünmektedir. Sevdiği kızla çıktıkları yolculukta, Edirne yakınlarında, Büyük Semiramis Oteli'nde bir gece kalırlar. Geceyi birlikte geçiren çift, sabah büyük bir tartışma yaşar. Yıllarca hayallerine ulaşması kendisini seven adam tarafından engellenen Füsun, bindikleri Chevrolet'yi öfkeyle bir ağaca doğru sürer:

“O zaman yaşadığım mutluluğun sonuna geldiğimizi, bunun bu güzel âlemden ayrılıș zamanı olduğunu ruhumda derinden hissettim. Son hızla çınar ağacına doğru gidiyorduk. Bizi o hedefe Füsun kilitlemişti. Böyle hissettim, kendime onunkinden başka bir gelecek de görmüyordum artık. Nereye gidiyorsak onunla birlikte gidiyorduk ve bu dünyadaki mutluluğu kaçırmıştık. Çok yazık olmuştu, ama bu sanki kaçınılmaz bir şeydi. 0 zaman yaşadığım mutluluğun sonuna geldiğimizi, bunun bu güzel âlemden ayrılış

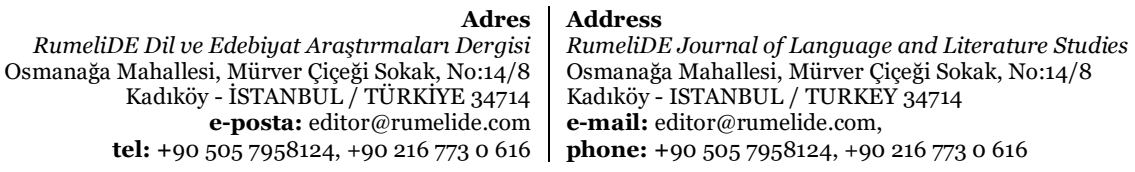

RumeliDE Journal of Language and Literature Studies

Osmanağa Mahallesi, Mürver Çiçeği Sokak, No:14/8

Kadıköy - ISTANBUL / TURKEY 34714

e-mail: editor@rumelide.com

phone: +90 505 7958124, +90 2167730616 
zamanı olduğunu ruhumda derinden hissettim. Son hızla çınar ağacına doğru gidiyorduk. Bizi o hedefe Füsun kilitlemiști. Böyle hissettim, kendime onunkinden başka bir gelecek de görmüyordum artık. Nereye gidiyorsak onunla birlikte gidiyorduk ve bu dünyadaki mutluluğu kaçırmıştık. Çok yazık olmuştu, ama bu sanki kaçınılmaz bir şeydi" (2014: 505).

Kazada Füsun ölür, Kemal ise güçlükle hayata tutunur. Yol, Kemal'in tutkuyla bağlı olduğu Füsun'u kaybettiği, ölümcül bir mekâna dönüşür. Bundan sonra ise Kemal için yeni yolculuklar söz konusudur. İleride kuracağı müze fikrinin temellerini bu yolculuklar sırasında atacak olan Kemal, ylllar boyunca dünyanın hemen her yerinde gezinir, gittiği şehirlerin sokaklarını keşfeder, müzelerini ziyaret eder.

Füsun'un kaza yaptığı Chevrolet'ye de yol kronotopuna katkısı bakımından değinmekte fayda vardır. Bir dönemin statü simgesi olan bu Amerikan arabası, Kemal'e babasından yadigâr kalır. Şoförü Çetin Bey'in kullandığı arabanın arka koltuğunda oturan Kemal, İstanbul sokaklarını, denizi, çevirme yapan darbe dönemi askerlerini seyreder. Bir zenginlik alameti olan Chevrolet ile akrabalar da gezdirilir. Kemal, bunun, 60 'lı yıllardan itibaren gelişen bir adet olduğunu anlatır. Ehliyet almayı çok isteyen Füsun'a da yine Chevrolet'de sürüş dersleri verir ve bu dersler sırasında İstanbul'u dolaşırlar. Başlamadan bitecek olan Avrupa seyahatine de yine bu araçla çıkarlar. Kemal, kazadan bir müddet sonra Chevrolet'nin enkazını bir hurdacıda bulur ve onu da sergilemek üzere müzesine taşır.

Yol-karşılaşma kronotopu Masumiyet Müzesi'nin olay örgüsünde belirleyici rol üstlenmekte, kişilerin karakterini belirgin kılmakta ve Chatman'ın da ifade ettiği gibi “anlatının ruh haline katkıda bulunmak"tadır (2008: 132).

\section{3. Ev kronotopu}

Salon kronotopunu açılayan Bahtin, evin herhangi bir odasının da benzeri duygu ve değerleri yüklenebileceğinden bahseder. Masumiyet Müzesi'nde buna uygun odalardan bahsedilebilir. Bununla birlikte öncelikle roman kişilerinin yaşadığı evlerin birer kronotop olarak değerlendirilmesi gerekir. "Çünkü evimiz bizim dünya köşemizdir. Bizim -sık sık yinelendiği gibi- ilk evrenimizdir. Ev, gerçek bir kozmostur" (Bachelard, 1996: 32). Ev, sadece barındırma işlevi görmez; insanın anılarını, düşlerini, düşüncelerini saklayan bir mekân olarak onu korur ve dış dünyaya karşı bir sığınak, bir dayanak noktası olur44.

İlk olarak Kemal'in ailesiyle birlikte yaşadığı Teşvikiye Camii karşısındaki apartman dairesi, modern Türk ailesinin mekânı olarak toplumsal bir anlam ifade etmesinin yanı sıra Kemal'in çocukluğuna dair hatıralarının şekillendiği bir huzur ve mutluluk imgesi olarak dikkat çeker. Füsun'u kaybettiği sıralarda, hayatın acı yönlerini tecrübe etmeye başlayan Kemal, Teşvikiye'deki evlerinin ve çevresinin huzur dolu atmosferinden medet umar:

“Dünya işte böyle güzel bir yerdi, yaz akşamında Boğaz yönünden esen poyraz, Teşvikiye Camii'nin avlusundaki çınar ağaçlarını taa çocukluğumdan beri hatırladığım hoş ve yumuşacık sesle hışırdatıyor; hava kararırken kırlangıçlar 1930'lardan kalma apartmanların damlarının ve caminin üzerinden çığlıklar atarak uçuyor; sayfiye evine gitmeyen Nişantaşlıların televizyonlarının ışığı hava karardıkça belirginleşiyor; bir balkonda canı sıkılan bir genç kız, daha sonra başka bir balkonda mutsuz bir baba, ana caddedeki trafiğe bir süre dalgın dalgın bakıyor; bense bütün bu manzarayı, kendi duygularımı seyreder gibi seyrediyor, Füsun'u hiç unutamamaktan korkuyordum. Orada kendi evimin balkonunun

4 Ayșe Demir, Bachelard'ın bireyi öne çıkaran bu ev yorumuna karșın, Türk edebiyatında evin bireyden önce "ailenin varlığını koruma ve onu bir arada tutma" işleviyle var olduğunu dile getirir (2011: 19). Bu durum modern Türk romanında bireyin lehine olarak değişir. Kemal'in önce Sibel'in yalısında yaşamak, daha sonra Füsun'u aramak ve nihayet onun hatırasını yaşatmak için baba evinden ayrılması aile bağlarından soyutlanarak bireyleşen, kendi düşünün peşinden giden bir özneye işaret eder.

RumeliDE Dil ve Edebiyat Araştırmaları Dergisi Osmanağa Mahallesi, Mürver Çiçeği Sokak, No:14/8 Kadıköy - İSTANBUL / TÜRKIYE 34714 e-posta: editor@rumelide.com tel: +90 505 7958124, +90 2167730616
Address

RumeliDE Journal of Language and Literature Studies

Osmanağa Mahallesi, Mürver Çiçeği Sokak, No:14/8

Kadıköy - ISTANBUL / TURKEY 34714

e-mail: editor@rumelide.com

phone: +90 505 7958124, +90 2167730616 
serinliğinde otura otura ve arada bana katılıp gevezelik edenleri tatlı tatlı dinleyerek, küp gibi içtim" (2014: 195-196).

Füsun'u bulamayan ve acıları yatıșmayan Kemal, Sibel'le de yollarını ayırırken ailesinin merak dolu bakışlarından korunmak için evden ayrılır ve Fatih Oteli'nde kalmaya başlar. Bir yandan da Füsun'u aramaya devam eden Kemal, yabancılarla bir arada kaldığı bu otelden babasının ölüm haberi üzerine çıkar ve annesinin yanına, evine döner:

"Eve dönmek, o dünyanın merkezine dönmek demek olduğu için kendimden saklayamadığım bir mutluluğum vardı ve babası ölen herhangi bir erkeğin duyduğundan daha yoğun bir suçluluk duyuyordum. Buzdolabında, ölmeden önceki gece babamın yanladığı bir küçük Yeni Rakı şişesi buldum, bütün konuklar gittikten sonra, annem ve ağabeyimle otururken dibine kadar içtim” (2014: 235).

Kemal, babasını kaybettiği için üzgün olmakla beraber, ölüm acısını bastıran bir mutluluk duygusu da taşır. İlk evrenine dönen bir adamın mutluluğudur bu; ev, tanıdık eşyalar ve kokularla geçmişi şimdiye bağlar.

Teşvikiye'deki evlerinde yer alan salon ise hem ailenin bir araya geldiği hem de bayram, düğün, cenaze gibi vesilelerle eve gelen misafirlerin ağırlandığı bir mekân olarak romanda yer alır. 1969 yılı Kurban Bayramı anılarını anlatan Kemal, o gün evin salonunu dolduran kalabalıktan bahseder; bu kalabalık misafirler arasında Füsun ve ailesi de vardır. Benzeri bir kalabalık, babasının ölümüyle yine salonda ağırlanır. Kemal gün boyu gelenlerle ve ailesiyle ilgilenir, hatta dedikodular yapar. Aile üyeleri yılbaşında da salonda toplanır ve tombala oynar. 70’lerin önemli bir aile eğlencesi olan bu oyuna büyük küçük herkes katılır ve Kemal'in annesinin hazırladığı hediyeler, kazananlara dağıtılır.

Salonda bulunan yemek masası da Kemal'in ailesiyle birlikte öğle ve akşam yemeklerinde buluştuğu bir mekândır. Burada günlük olaylar konuşulur. Özellikle Füsun'un ölümünün ardından yıllarca anne-oğulun sevdiklerini yitirmiş insanların duygudaşlı̆̆ıla oturduğu yemek masasında gündelik konuşmalar, dedikodular yapılır; büyük olaylar gerçekleşmez, huzursuzluk çıkmasına izin verilmez 5 .

Ev kronotopu içinde ele alınacak bir diğer mekân ise Kemal'le Füsun'un yasak aşkına sahne olan Merhamet Apartmanı'dır. Cumhuriyet'in ilanının ardından yükselen yeni burjuva sınıfı mensuplarından bir aileye ait olan bu apartmanda Kemal'in annesine ait bir daire bulunmaktadır. Evdeki eski veya modası geçmiş eşyaların tutulduğu bir depo kimliği taşıyan bu daireye Füsun'u davet eden Kemal, onunla kısa ama tutkulu bir ilişki yaşar. Bahçeye bakan penceresiyle evin dışındaki varlıklara, kuş seslerine, çocuk bağırışlarına da kulak veren bu daire Kemal ve Füsun'un aşklarının masumiyetini, çocuksuluğunu temsil ettiği kadar, bu masumiyetin kaybına da atıfta bulunur. Füsun'a söylediği yalanlarla ona merhamet göstermeyen, aşkının kıymetini bilmeyen Kemal'in bencilliği bu dairede ve onun tozlu eşyalarında, küf kokulu divanında yankı bulur. Bu bakımdan apartmanın ismi de sembolik bir değer taşımaktadır.

Kemal, Füsun'u kaybettikten sonra garip bir tutkuyla onu hatırlatan eşyaları bu dairede biriktirmeye başlar. Füsun'un elinin değdiği objelerden, içtiği sigaranın izmaritine, dondurma külahından, mendile hemen her nesne onun koleksiyonunun bir parçası olarak dairede yerini alır.

“Merhamet Apartmanı'ndaki daireye gider, orada Füsun ile yaşadığımız mutlu saatleri düşünerek hayallere dalarken, gittikçe büyüyen "koleksiyonuma" hayret ile şașkınlık arası bir duyguyla bakardım.

$5 \quad$ Esra Topuz'un hazırladığı Edebiyat ve Yemek: Bir Kronotop Olarak Yemek başlılı yüksek lisans tezinde de Masumiye Müzesi romanında kişilerin bir araya geldiği yemek masasında olay örgüsünü derinden etkileyecek bir değişimin, kişisel dönüşümün yaşanmadığı dile getirilir (2012: 43-51). Bununla birlikte özellikle Kemal’in Füsunların evinde yaklaşık sekiz yıl boyunca oturduğu yemek masasında hemen her zaman aynı durumların tekrar etmesi, evin zamandışılığına vurgu yapılması bakımından değer taşır. Bu, vakitleri belirleyen radyo, televizyon ve ezan gibi nesnel zaman işaretlerinden ayrı olarak var olan Füsun ve ailesinin özel zamanıdır (2014: 296).

Adres Address

RumeliDE Dil ve Edebiyat Araştırmaları Dergisi Osmanağa Mahallesi, Mürver Çiçeği Sokak, No:14/8 Kadıköy - ISTANBUL / TÜRKIYE 34714 e-posta: editor@rumelide.com

RumeliDE Journal of Language and Literature Studies Osmanağa Mahallesi, Mürver Çiçeği Sokak, No:14/8

Kadıköy - ISTANBUL / TURKEY 34714 tel: +90 $5057958124,+902167730616$

e-mail: editor@rumelide.com

phone: +90 505 7958124, +90 2167730616 
Hiç durmadan biriken bu eşyalar, yavaş yavaş aşkımın yoğunluğunu gösteren işaretlere dönüşüyordu. Onlara Füsun ile yaşadığım mutlu saatleri hatırlatan teselli edici șeyler gibi değil, ruhumda esmekte olan bir fırtınanın elle tutulur uzantılarıymış gibi bakardım bazan. Bazan da biriktirdiğim şeylerin varlığından utanır, başkalarının onları görmesini hiç istemez, gittikçe artan eşyaların bu gidişle birkaç yılda Merhamet Apartmanı'ndaki dairenin odalarını baștan aşağı kaplayabileceğini aklıma getirir, korkardım" (2014: 377).

Kemal sık sık bu daireye giderek, birlikte vakit geçirdiği eşyalar sayesinde Füsun'un yokluğuna bir nebze olsun katlanabilir. Bununla birlikte zamanla bu eşyaların roman kahramanı için birer fetiş nesnesine dönüştüğü de görülür. Füsun'un ölümünden sonra bu eşyaları düzenleyerek sergilemek ve aşkına ölümsüzlük katmak isteyen Kemal, bir müze kurmaya karar verir.

"Masumiyet Müzesi” adını vereceği bu yer ise Füsunların Çukurcuma'daki evleridir. Füsun kendisini terk ettikten yaklaşı bir buçuk yıl sonra Kemal, onu ilk kez bu evde ziyaret eder. Kemal için burası bir tapınaktır. Zira ev, tutkuyla bağlı olduğu, zihninde idealize ederek bir tapınma nesnesine dönüștürdüğü kadının sessiz, sakin ve pek de özgür olmadan yaşadığı bir mekândır. Kemal, yaklaşık sekiz yıl boyunca haftanın birkaç akşamını bu evde geçirir. Takıntılı bir âşık olan Kemal, bu ziyaretlerin hepsini kaydetmiştir:

\begin{abstract}
“Tam yedi yıl on ay, Çukurcuma'ya, Füsun'u görmeye akşam yemeğine gittim. İlk gidişim Nesibe Hala'nın 'Akşamları bekliyoruz!' demesinden on bir gün sonra, 23 Ekim 1976 Cumartesi olduğuna ve Çukurcuma'daki son akşam yemeğimizi Füsun, ben ve Nesibe Hala 26 Ağustos 1984 Pazar günü yediğimize göre, aradan 2864 gün geçmiş. Hikâyesini anlatacağım bu 409 haftada, notlarıma göre onlara 1593 kere akşam yemeğine gitmişim. Ortalama haftada dört kere demektir bu, ama haftada dört gün hiç şaşmadan Çukurcumaya akşam yemeğine gittiğim de sanılmasın” (2014: 291).
\end{abstract}

Bu ziyaretlerin sıklığına şaşıracak okuru ise zamanın göreceli olduğu konusunda uyarmayı ihmal etmez Kemal. 0, aşkı için Füsunların kapısını defalarca aşındırmıştır. Kemal, Füsun'u görmeye gittiği kadar onun âlemini tanımak, soluduğu atmosfere yakın olmak için de Çukurcuma'daki eve gider. Burası Kemal'e göre "zamandışı" bir yerdir: "Müzemizi ziyarete gelen meraklının, Keskinlerin bütün eski eşyalarına, bozulmuş, paslanmış, yıllardır çalışmayan çalar saatlerine, kol saatlerine bakarken, bu 'zamandışı' tuhaflığı ya da bu şeylerin kendi aralarında oluşturdukları özel zamanı fark etmesini isterim. Bu özel zaman Füsunların evinde ylllarca soluduğum ruhtur" (2014: 296).

Zamanı Aristo'nun kuramında olduğu gibi bir çizgi olarak ele almak istemeyen Kemal, "şimdi"ye, anlara odaklı bir zaman anlayışı geliştirir. Çizgisel zaman, nihayetinde bitişlere, yani ölüme işaret eder. Oysa bir an için tadılan mutluluk, kişiyi çok uzun süreler mutlu edecek güce sahiptir:

“... 'şimdi' dediğimiz anlar, Çukurcuma’ya akşam yemeklerine gitmeye başladığım günlerde olduğu gibi, Füsun'un bir gülümseyişiyle, bazan bir yüzyıl yetecek kadar mutluluk verebilir bize. Keskinlerin evine hayatımın geri kalanında bana yetecek mutluluğu almaya gittiğimi daha baştan anlamıștım ve evlerinden Füsun'un dokunduğu irili ufaklı küçük eşyaları, bu mutlu anları saklamak için alıp götürüyordum" (2014: 298).

Füsun'la yakaladığı mutlu anları zihninde ve topladığı eşyalarda sabitlemeye çalışan Kemal için o evde geçirilen her gece, en umutsuz olanları bile, ylllar boyunca kendisine mutluluk vermeye devam edecektir. Füsun öldükten sonra ise Kemal, burayı artık bir telafi mekânına dönüştürmek ister. Füsun'un özgür bir kadın olarak çıkamadığı ve çizdiği kuş resimleriyle teselli bulduğu bu aile evi, Kemal tarafından aşkının sonsuza dek yaşatılacağı bir kişisel müze hâline getirilir.

Yine ev kronotopu çerçevesinde ele alınabilecek bir diğer zaman-mekân ise Sibellerin Anadoluhisarı'ndaki yalısıdır. Yalı eski ve harap bir binadır. Yine de așk acısını atlatmak isteyen Kemal, nişanlısı Sibel'in de desteğiyle yaz mevsimini burada, yalı hayatının sunduğu çeşitli zevkleri tadarak geçirir. Canı istediğinde

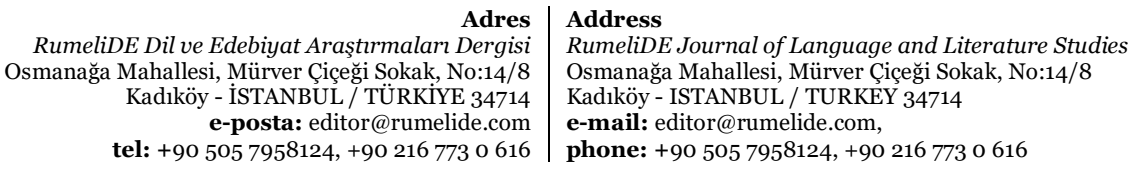


denize atlayıp yüzmek, yalıya yanaşan balıkçılardan balık almak, arkadaşlarla eğlenceler tertip etmek bunlardan bazılarıdır. Bu eğlenceler arasında Sibel, Kemal'in Füsun'u unutabileceğini ümit eder:

\begin{abstract}
"Yeni bir hayata başlamanın coşkusuyla hemen benimsediğim yalı hayatının tesellileri, ilk günlerde beni hastalığımdan hızla kurtulmakta olduğuma inandırdı. Gece hangi eğlenceden, hangi saatte ve ne kadar sarhoş dönmüş olursak olalım, sabah Boğazın dalgalarında yansıyan tuhaf bir ışık panjurların arasından sızıp odamızın tavanında oynaşmaya başlar başlamaz yataktan kalkar, panjurları parmaklarımın ucuyla itip açar ve içeriye patlar gibi dolan manzaranın güzelliğine her seferinde hayret ederdim. Hayretimde, hayatın unutmakta olduğumu sandığım güzelliğini yeniden keşfetmenin heyecanı da vardı ya da ben öyle inanmak istiyordum" (2014: 202-203).
\end{abstract}

Fakat yaz sonuna kadar Füsun'u unutamayan Kemal'in durumu giderek vahim bir hâl almaya başlar. Bu ise ona şefkatle ve bağışlayıcılıkla yaklaşan Sibel'i ümitsizliğe düşürür. Giderek hüzünlü bir çifte dönüşen nişanlılar, yine de bu eski binada kendilerini mutlu hisseder:

“Öte yandan ikimiz de ihtişamını kaybeden bu eski yalıda birlikte yaşamaktan memnunduk. Durumumuz ne kadar umutsuz olursa olsun, köhne binada bizi birbirimize bağlayan ve acımızı güzelleștirerek dayanılır kılan bir şey vardı. Yalı hayatı artık canlanmayacağı anlaşılan aşkımızı bir çeşit yenilgi, kader ve yoldaşlık duygularıyla derinleștiriyor, yok olan Osmanlı kültürünün son kalıntıları biz eski âşı, yeni nişanlıların hayatlarındaki 'eksikliğe' bir derinlik katıyor, hatta bizi sevişememenin acılarından koruyordu" (2014: 213).

Burada yalıyı Bahtin'in “şato kronotopu”yla da ilişkilendirmek mümkündür. Ne de olsa yalı, Osmanlı kültürünün ve Boğaziçi'nde sürdürülen zevk-i selimin bir yansımasıdır. Ama bu mekân, soğuk mevsimler için uygun bir yer değildir. Aralarındaki ilişkinin aşktan başka bir şeye dönüşmesi ve Kemal'in merhametli nişanlısının ilgisinden daimi bir surette faydalanarak bencillik etmesi nişan bağını zayıflatır. Köhne yalıya gelen sonbaharla birlikte ikilinin arasına da bir soğukluk girer. Sibel, duygularını istismar eden Kemal'den uzaklaşır. Ama nişanı da kolaylıkla atamaz. Çünkü yaz boyunca yalıda geçirdikleri evlilik öncesi bu çift hayatı, "modern" de olsa sosyete mensupları için bile dedikodular ve kınamalara kapı aralamıștır.

Ev imgesi, bazen salon ve yatak odası gibi unsurlarıyla birlikte Masumiyet Müzesi romanında zaman-mekân ilişkisini yansıtır. Zamanın nesnel ve öznel olarak hissedildiği evler kişileri barındırır, onlara düşler kurdurur. Bachelard'ın deyişiyle "içinde oturulan mekân, geometrik mekânı aşar" (1996: 72). İnsanla etkileşim hâlinde olan ev, kendi değiştiği gibi insanı da değiştirir. Hatıraların yoğunlaştığı ev kronotopunda, zaman derinlik kazanır.

\title{
1. 4. Eşik kronotopu
}

İnsan hayatını şekillendiren ani kararların, krizlerin mekânı olan eşik kronotopu, Masumiyet Müzesi kahramanlarının da hayatlarına yeni bir yön verir. Kemal'in davetine uyarak Merhamet Apartmanı'na giden Füsun, kapı eșiğinde yaşadığı kısa süreli kararsızlğın ardından daireye girer ve başkasıyla nişanlanacak olan bu uzak akrabasıyla ilişki yaşamaya başlar. Bu ilişki içinde cinselliği tadan Füsun, masumiyetini yitirirken Kemal'le birlikte yeni deneyimlere doğru yol alır. Bununla birlikte yaşadığı ilişkinin bedelini ağır bir şekilde öder; aşk kafasını karıştırdı̆̆ı için üniversite sınavına çalışmayan Füsun okuma ve kendi ayakları üzerinde durma imkânını kaybeder. Âşık olduğu Kemal'in söylediği yalanları öğrendiğinde ise güven duygusunu yitirir. Kemal yüzünden içine düştüğü zor durumdan pek de sevmediği biriyle evlenerek kurtulmaya çalışır. Sinema yıldızı olma hayalleri de yine Kemal tarafından engellenen genç kadın, evlenmeden önce kaldıkları otelde Kemal'in odasına gitmek suretiyle ikinci bir hata yapar. Neticede istediği hayatı yaşayamayacağını ve anlaşılmadığını düşünen Füsun ölüme yürür.

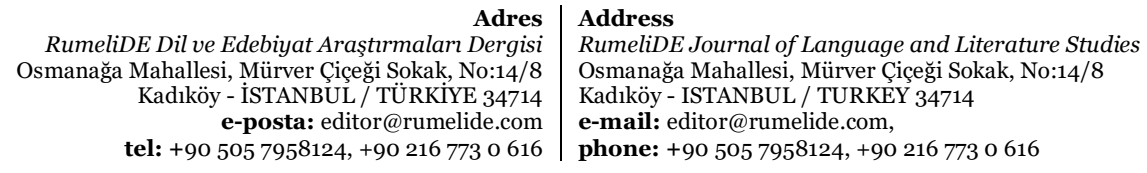


Kemal de Merhamet Apartmanı'ndaki dairenin eşiğinden Füsun'u içeri aldıktan sonra hayatını değiștirecek bir aşk yaşamaya başlar. Çevresi tarafından uygun bir eş olarak görülmeyen Füsun'la yasak bir ilişki içine girer. Bu sırada nişanlanacağı Sibel'den de ayrılmayı düşünmeyen Kemal, hayatın güzelliklerinin, mutluluklarının bir tepside kendisine sunulduğu düşüncesindedir. Oysa Füsun'un kendisini terk etmesinin ardından Sibel'den de sosyetik çevresinden de giderek uzaklaşır, içine kapanır. Bu mutsuzluk onu ölüme sürüklerken karşısına ikinci bir şans çıkar. Füsun'un davetiyle gittiği Çukurcuma'daki evin eşiğinde sevdiği kadını bulmanın sevinci ve evlenme ümidi taşıyan genç adam, Füsun'un Feridun isimli bir senaristle evlendiğini öğrenir. Eşikte tanıştırıldığı damat beyin varlığını kabul etmek istemez. Yaşadığı hayal kırıklı̆ının ardından, bir daha o eve adım atmamaya karar veren Kemal, yine de iradeli davranamaz; Füsun'a duyduğu büyük arzu, buna engel olur. 0 eşikten, sonraki sekiz yıl boyunca, bile isteye defalarca geçer.

Eşik, bağlantılı olduğu koridor, sahanlık gibi mekânlarla birlikte Masumiyet Müzesi'nin âşıklarının hayatlarını bir daha asla eskisi gibi olmayacak şekilde değiştirir. Yoğun duygu değeri taşıyan bu eşik kronotopunda gerek Füsun gerek Kemal kararsızlı yaşasalar da aşk ve tutku gibi duyguların esaretinde, kader eşiğinden atlarlar. Böylece kendilerini deneyimin kollarına bırakan ve masumiyetlerini yitiren sevgililer, farklı bedeller öderler. Eşikten atlayarak çıktıkları yolculuğun sonunda Füsun, ölümü tercih eder. İsminde kendini açı eden büyülü ve hayali bir varlığa dönüşür. Kemal ise bencilliklerine kurban ettiği aşkına olan kalbî borcunu bir müze kurarak ödemeye çalışır. Onun aşkı yıllar içinde Füsun'un da varlığını aşan ve âlemi içine alan bir duyguya dönüşür. Bu da romanı Kemal'in olgunlaşma hikâyesine dönüştürür (Parla, 2018a: 54). Kemal, kendini kapattı̆̆ı müze-evde Füsun'u ve Füsun'un kokusunun sindiği, gözlerinin değdiği İstanbul'u yaşatır.

\section{5. Kapı kronotopu}

Kapı, açık veya kapalı oluşuna göre olay örgüsünde anlam kazanan bir kronotop olarak karşımıza çıkar. Bir kapı sadece varlık olarak değil, açmak, kapamak gibi fiillerle birlikte de düşünülmelidir. Açılan bir kapı, mekânlar arasındaki geçişe izin verir ve mahremiyeti ortadan kaldırır. Kapalı bir kapı ise bu iznin olmadığını gösterir. Kapının açılması veya kapanması durumları ise bu fiilleri gerçekleştiren kişilerin varlığına işaret eder. Bir kapının açılması ve kapanması, bazı olayların da tetikleyicisi olabilmektedir (Demir, 2011: 352-353).

Masumiyet Müzesi romanında da kapı kronotopunun bazı işlevler yüklendiği görülür. Kemal, Şanzelize Butik'in kapısını açıp içeri girer ve Füsun'la karşılaşır. Bu romanda anlatılacak olayların tetikleyicisi olur. Yine Kemal, rüyasında Merhamet Apartmanı'na davet ettiği Füsun'a kapıyı açtığını görür. Burada rüyayla birleşen kapı imgesi yeni bir ilişkinin başlayacağının işareti olur. Daha sonraları Kemal, Merhamet Apartmanı'nda buluşmaya başladığı Füsun'u kaybetmemek için ona dairenin kapısında yalvaracaktır.

Kemal, Füsun'u kaybettiğinde, ilk olarak oturdukları Kuyulubostan Sokak'taki eve gider. Kapıya defalarca vurur, zile basar ama kimse cevap vermez. Kapı burada bir duvara dönüşür ve Kemal'in Füsun'a ulaşmasını engeller. Füsun ve ailesi bu evden taşınmıştır ve artık ondan haber almanın bir imkânı yoktur.

Aylar süren arayıştan sonra Kemal, Füsun'u Çukurcuma'da bulduğunda heyecanla ailenin kapısına varır: "Kalbim hızlanarak kapıyı çaldım. Az sonra Nesibe Hala kapıyı açtı; bisikleti getirirken, arkamdan bana șemsiye tutan Çetin Efendi'den ve elimdeki güllerden etkilendiğini hatırlıyorum. Kadının yüzünde bir huzursuzluk vardı, ama üzerinde durmadım; çünkü merdivenlerden, basamak basamak Füsun'a

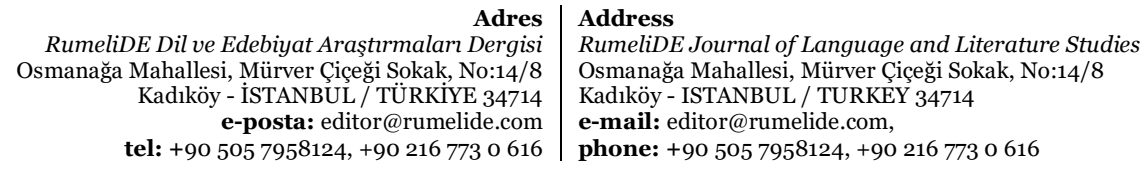


yaklaşıyordum" (2014: 245). Kapı bu kez açılmış, Kemal'e giriş izni verilmiştir. Kemal, bu dakikada Füsun'a kavuştuğu düşüncesiyle sevinir.

Kemal'in sonraki ziyaretlerinde kapıyı hep Nesibe Hala açar. Başka zamanlarda, gelen misafire kapıyı açanın Füsun olduğunu gören Kemal, o eve niçin geldiğini ailenin anladığını hisseder. Kapının açılması Füsun'un babası, annesi, eşi ve kendisinin Kemal'in evdeki varlığından rahatsız olmadıklarının bir işaretiyken, kapıyı açanın Nesibe Hala olması, ona bazı sınırları aşmaması gerektiğini hatırlatır.

Kemal'in Füsun'un evli olduğu gerçeğini hazmedemediği ilk ziyaretinde ise banyoya kendini kapattığı görülür. Kapıyı kapatıp sarhoşluğun etkisiyle bir müddet oradan çıkmayan Kemal, Füsun'un öksürüğünü duyduktan sonra biraz olsun kendine gelir. Burada kapı, kişinin kendisini dış dünyaya, acı gerçeklere ve iletişime kapatmasını sağlar.

Masumiyet Müzesi romanında kapı, açık ve kapalı olmasına göre umudun yahut hayal kırıklığının mekânı olabilmektedir. Ayrıca romanda yer alan eșik kronotopuyla birlikte düşünülebilecek olan kapı, kimi zaman sınır durumların yaşandığı bir yere de dönüşür.

\section{6. Pencere-balkon kronotopu}

Pencere ve balkonlar, kapıların haricinde, bir evin dış dünyayla ilişkilerini şekillendiren yerlerdir. Pencerenin açık olup olmaması, perdesinin takılı olup olmaması veya pencereden bir ışığının sızıp sızmaması bir evin yuva olup olmadığını gösterebilir. Bu, evin dışından bakan kimsenin gözleyebileceği bir durumdur. Buna karşılık olarak evde yaşayanlar da dışarıyı pencerelerden, balkonlardan seyrederler. Dışardaki olayları, insanların gidiş gelişlerini bu yerlerden takip ederler; dışarda bulunan insanlarla iletişime geçerler.

Masumiyet Müzesi'nde pencerenin hem dışardan bakan için hem de içerde oturanlar için bazı değerler taşıdığı görülür. Kemal, kıskançlık krizi geçirdiği bir akşam, Füsun'un Kuyulubostan Sokak'taki evine gider; pencereden sızan ıșığı, onun evde oluşunun bir işareti sayar. Yıllar sonra Kemal, baktığı bu pencere manzarasını resmettirerek Masumiyet Müzesi'nde de sergiler ve "müzegezer"in de, o akşam kendisinin yaşadığı kıskançlığı hissetmesini ister. Füsun, Kemal'i terk ettikten sonra daha fazla dayanamayıp yine bu eve giden Kemal, bu kez pencerelerin perdesiz olduğunu görür ve Füsunların taşındıklarını anlayarak yıkılır.

Pencere önü ise, Kemal'in Füsun'u Çukurcuma'daki evlerinde bulduktan sonra yaptığı ziyaretlerde de sıklıkla durduğu bir konum hâline gelir. İlk ziyaretinde, yağmurun sokakta meydana getirdiği küçük bir seli ve sel sularının evlerine girmemesi için uğraşan mahalleliyi Füsun'un aile üyeleriyle birlikte ilgiyle seyreder.

Sonraki yıllarda, çoğu vaktini evde geçiren Füsun'la birlikte pencere önünde dikilerek dışarıyı seyreder ve sohbet ederler. Bu kısa sohbet anları, Kemal'in Füsun'a fiziksel olarak de en yakın olduğu zaman dilimlerini teşkil eder. Bunlardan birini ayrıntılarıyla anlatan Kemal'in, kısacık anlara sığdırdığı mutluluk ve sevdiği kadının hareketlerinde yakaladığı incelik dikkat çekicidir:

"Bana kalırsa, o gece Füsun, masadan kalkıp yanıma bana yakınlık göstermek için gelmişti. Yanımda sessizce durup, bu sıradan manzaraya bakması da bunu gösteriyordu. Sırf Füsun yanımda olduğu için bana olağanüstü şiirsel gözüken kiremitlerle çinko damlara, dumanı hafifçe tüten bacalara, aydınlık pencerelerdeki ailelerin ev içlerinde hareket edișine bakarken, içimden elimi Füsunun omzuna koymak, ona sarılmak, ona dokunmak geliyordu... Şu anlattığım ikilemle sekiz yıl çok düşünmüş, çok kahrolmuşumdur. Pencereden dışarıya, burada bir resmini sergilediğim gece manzarasına en fazla iki-iki buçuk

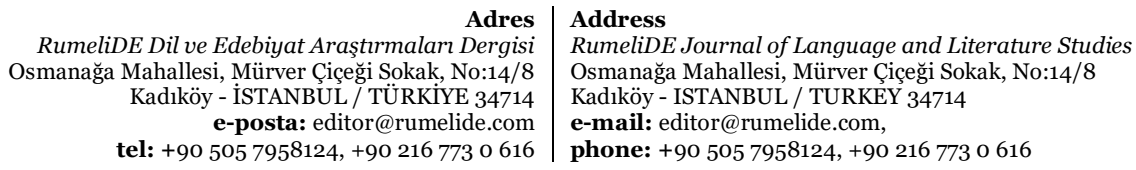


dakika baktık. Müzegezer bu manzaraya bakarken benim ikilemimi içinde hissetsin lütfen ve Füsun'un bu konuda çok ince ve zarif davran dığını unutmasın" (2014: 309-310).

Küçük anlara ve mekânlara sığdırılan bu duygu derinliğinin bir başka ilgi çekici örneği de yine Çukurcuma'daki evde gerçekleşir. İlk ziyaretinde Füsun'un evlendiğini öğrenen Kemal, sarhoşluğun da etkisiyle, kendini kapattığı banyoda epey bir müddet oyalanır ve dışarı çıkmak istemez. Küçük evin, küçük banyosunda gerçeklerden kaçmaya çalışan ve mekânda olduğu kadar zamanda da sıkışan Kemal, banyo penceresinden gelen bir sese kulak verir:

\begin{abstract}
"Yağmurun uğultusu ve su borularının gurultusu arasında, çocukluğumda babaannemin dinlerken mutlu olduğu eski alaturka şarkılardan birini duyuyordum. Yakınlarda bir yerde açık bir radyo olmalıydı. Udun baygın iniltisi ve kanunun neşeli tımbırtısı arasından yorgun ama umutlu bir kadın sesi, banyonun yan açık küçük penceresinden bana ulaşıyor ve 'Așktır, aşktır âlemde her şeyin sebebi," diyordu. Bu kederli şarkının da yardımıyla, banyodaki aynanın karşısında hayatımın en derin ruhsal anlarından birini yaşadım ve âlemin, bütün eşyanın bir bütün olduğunu anladım. Yalnız önümdeki dış fırçalarından sofradaki kiraz tabağına, Füsun'un o an fark edip cebime indirdiğim firketesinden banyo kapısının burada sergilediğim sürgülü kilidine kadar bütün eşyalar değil, bütün insanlar da birlik içindeydi. Yaşadı̆̆ımız hayatın anlamı, așkın gücüyle bu birliği hissetmekten ibaretti” (2014: 252).
\end{abstract}

Kısa bir süre için evin banyosunda çocukluk hatıralarına dönen Kemal, radyodan yükselen aşk şarkısının kendisinde uyandırdığı hislerle âlemin birliğini, bütünlüğünü sezer gibi olur ve aşkın birleştirici gücünü kavrar. Bu anlık kavrayış, romanın devamında, yaşadığı acıya rağmen, Kemal'in aşkına sadık kalacağının ve Füsun'u sevmekten vazgeçmeyeceğinin bir işareti olarak okunabilir.

Balkon da pencere gibi işlevler taşır romanda. Teşvikiye'deki dairelerinde Kemal ve annesi, balkonda oturup kahvelerini içer, sohbet ederler. Bu balkon, ayrıca apartmanın karşısında bulunan Teşvikiye Camii'ndeki cenaze törenleri için de bir seyir mekânı işlevi görür. Kemal'in annesi Vecihe Hanım, balkonunda oturarak dönemin sosyetesinin cenazelerini takip eder. Kocası ve oğlu Kemal öldüğu zaman da acılarına dayanamayan Vecihe Hanım, cenazeye katılamaz ve yine bütün töreni balkondan izler.

Teşvikiye'deki evde yapılan yaz sonu partisinde de balkon önemli bir duygu değeri taşır. Kemal, gece boyunca balkondan çevresini seyrederek Füsun'u unutmaya çalışır. Parti sabah karşı bittiğinde, arkadaşları denize gitmeye karar verir. Kemal ve nişanlısı Sibel evde kalır:

“Derken Mehmet'in arabası patinaj çekerek gidip sert bir frenle durdu, geri geri geldi, durdu, kapısı açıldı ve Nurcihan çıkıp bütün gücüyle altıncı kata, bize bağırarak ipek fularını unuttuğunu söyledi. Sibel içeri koştu, fuları getirip balkondan caddeye attı. Mor fuların, ağır ağır aşağı inerken, belli belirsiz rüzgârda bir uçurtma gibi nazlanarak açlıp kapanışını, şişip kıvrılışını Sibel ile annemin balkonundan seyredişimizi unutamam hiç. Nişanlımla son mutlu hatıramız budur" (2014: 198).

Yine kısa bir zaman diliminde yakalanan küçük bir mutluluk peşindedir Kemal, Sibel'le havada süzülen fuları seyrederken hayatın hâlâ güzel olabileceğini, mutluluğu yakalayabileceğini düşünür.

Kemal, 12 Eylül 1980 sabahında da bir içgüdüyle erkenden kalkıp bu balkondan dışarıyı seyreder. Boş sokaklarda ara sıra marş söyleyen askerleri taşıyan kamyonlardan başka bir şey yoktur. Bu durum askeri bir darbe yapıldığını gösterir. Beş yıl önceki partinin sabahında da Sibel'le balkonda durup aynı manzaraya baktığını hatırlayan Kemal, șehrin sessizliğinden ve rüzgârda hışırdayan yaprakların sesinden keyif alır.

Pencere-balkon kronotopu Masumiyet Müzesi'nde olay örgüsünü besler ve kişilerin iç dünyasını yansıtır. Küçük ölçekli olmakla birlikte pencere ve balkonlarda geçirilen kısa sürelerde uzun soluklu duygulanmalar yaşanır ve derin düşüncelere dalınır.

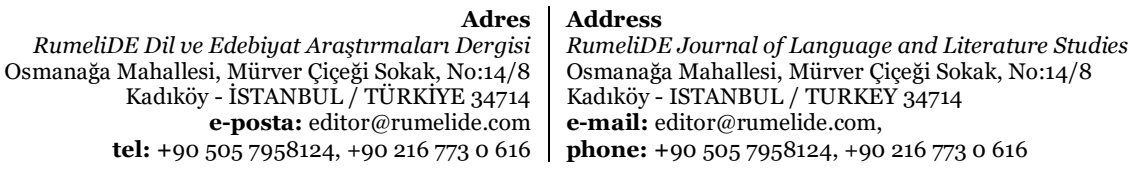




\title{
1. 7. Cekmece-dolap-sandık kronotopu
}

Bachelard'ın Mekânın Poetikası'nda üzerinde durduğu çekmece-dolap-sandık kronotopu, zamanın mekânlaştığı küçük, fakat anlam ve duygu derinliği itibariyle büyüyebilen bir yerdir. Bunlar, içlerinde yalnızca bazı kullanılmayan, eski eşyaları barındırmaz. Bu eşyaların sahipleriyle kurduğu dolaylı-dolaysız, yüzeysel veya derin ilişskinin de sığınağı dolaplar, çekmeceler ve sandıklardır:

"Dolap ve dolap rafları, çalışma masası ve çekmeceleri, sandık ve sandığın ikili zemini, gizli psikolojik yaşamın gerçek organlarıdır. Bu 'nesneler' ve bunlar kadar değerli kılınmış bazı başka nesneler olmasaydı, içsel yaşamımız içsellik modelinden yoksun kalırdı. Bunlar karma nesnelerdir, nesneöznelerdir. Bizim gibi, bizimle, bizim için bir içselliğe sahiptirler"(Bachelard, 1996: 100).

Masumiyet Müzesi de Kemal Basmacı'nın ve onun temas ettiği başka hayatlara dair küçük ayrıntıların, "içsel yaşam"ların sergilendiği bir bellek romanıdır. Hem bireysel hem toplumsal belleğin devinim hâlinde olduğu bu romanda çekmeceler, dolaplar ve küçük kutular insanların değer verdiği, anılarında sakladığı yahut bir kenara bırakıp unuttuğu nesnelerin mekânı olarak görünürler.

Teşvikiye'deki dairede verilen yaz sonu partisi biterken, denize gitmeye hazırlanan gençler arasından Nurcihan, mayo aramak bahanesiyle Kemal'in annesinin dolaplarını karıștırır. Kemal'in anne-babasının kolonya, halı ve çocukluk kokan yatak odalarındaki dolapta, çekmecelerde neler yoktur ki:

\begin{abstract}
"Yattığım yerden annemin ta 1950 'lerden kalma işlemeli çoraplarını, toprak rengindeki ipli ve zarif korselerini, Merhamet Apartmanı'na sürgüne yollamadığı şapkalarını, eşarplarını karıştırdığını görebiliyordum. Nurcihan, annemin bankadaki kasasına güvenmediği için naylon çoraplarının durduğu çekmecenin arkasındaki bir çantada sakladığı ev, arsa, apartman dairesi tapularını, kimileri satılmış, kimileri kiraya verilmiș dairelerin artık ișe yaramayan deste deste anahtarlarını, otuz altı yıl önce bir gazetenin dedikodu sütunundan kesilmiş babamla düğününün haberini, bundan on iki yıl sonrasının tarihini taşıyan Hayat dergisinin "Cemiyet" sütunundan kesilmiş ve annemi bir kalabalık içinde çok şık ve havalı gösteren bir fotoğrafi da sabırla elden geçirdi" (2014: 197).
\end{abstract}

Böyle bir elden geçirmeyi Kemal, babasının ölümünün ardından yapar. 0, dolapları ve çekmeceleri çocukluğunun hatırasını canlandıran eşyaları bulmak ve onlara dokunmak için karıştırır. Babasının ölümüyle bu eşyaların her biri "geçmişi taşıyan değerli şeylere" dönüşür (2014: 235). Kemal, babasının takma dişlerini cebine atarak koleksiyonuna dâhil eder.

Tarık Bey'in ölümünden sonra, onun çekmecelerini de karıştıran Kemal, babasınınkine benzer şekilde ilaç kutuları, şuruplar, faturalar bulur.

Şüphesiz, Kemal'in dolap ve çekmecelerinin çekimine kapıldığı asıl isim Füsun olur. Onun hazin ölümünün ardından eşyalarıyla teselli bulmaya çalışan Kemal için bu çekmeceler hazine değeri taşır:

"Yıllar boyunca akşamları ona hediye getirdiğim bütün tarakları, saç fırçalarını, küçük aynaları, kelebek biçimindeki broşları, küpeleri, her şeyi, Füsun, küçük odasındaki küçük dolapların gözlerinde saklamıştı. Ona hediye ettiğimi bile unuttuğum mendilleri, tombalalık çorapları, annesine aldığımızı sandığım tahta düğmeleri, saç tokalarını (ve Turgay Beyin hediye ettiği oyuncak Mustang'ı), ona yazıp Ceyda ile yolladığım aşk mektuplarını çekmecelerde bulmak beni manevi bir yorgunluğa sürükler, orada Füsun'un yoğun kokusunu taşıyan dolapların, çekmecelerin önünde yarım saatten fazla kalamazdım. Bazan yatağın kenarına oturur, sigara içerek dinlenir, bazan da gözyaşı dökmemek için pencereden dışarı, kuşları resmettiği balkonlardan birinden dişarı bakar, bazan da çoraplardan, taraklardan birini-ikisini yanıma alıp götürürdüm" (2014: 510).

Dolaplar ve çekmeceler Masumiyet Müzesi romanında birer "içtenlik mekânı" (Bachelard, 1996: 101) olarak var olurlar. Bazen sahiplerinin yahut emanetçilerinin izniyle, bazen de izin almadan açılan bu küçük gizem

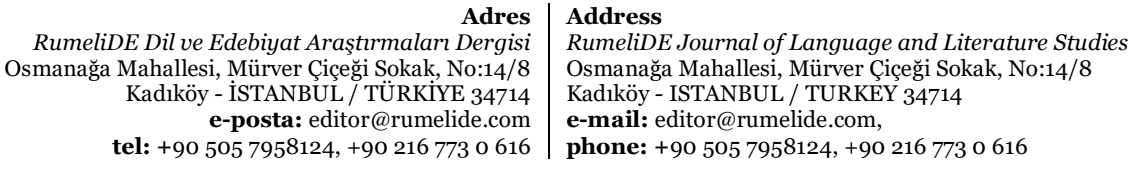


mobilyaları, içlerinde meraklılarına nice hatıra yükü taşıyan irili ufaklı nesneler saklar. Bunlar, dolap ve çekmeceleri karıştıranların hayal gücünü harekete geçirir. Kimi zaman da kaybedilen sevgililerin geride bıraktıklarını saklayan bu mekânlar, özlemle dolu yüreklere bir avuntu imkânı sunabilir. Yine de sakladıkları yoğun duygular ve geçmişin ağırlığı sebebiyle hacimlerinden fazlasını taşır gibidirler.

\title{
1. 8. Müze kronotopu:
}

Müzeler, dolap ve çekmecelerin büyük ve çok boyutlu çeşitleri gibidir. Toplumsal belleği taşıyan büyük ulusal müzelerin yanı sıra özellikle bireysel belleğin taşıyıcısı olan kişisel müzeler, Masumiyet Müzesi romanı bağlamında kronotop olarak ele alınması gereken bir duygu ve değer yükü taşır.

Orhan Pamuk'un Yeni Hayat ve Kara Kitap'ta da izini sürdüğünü ifade ettiği kişisel müze fikri, Masumiyet Müzesi'nde romanın tamamına yayılır (2020: 390). Romanın kahraman-anlatıcısı Kemal Basmacı, yaşadı̆̆ı anları, Füsun'a duyduğu büyük aşkı ve bu büyük aşkın şahidi olan İstanbul'u irili ufaklı objeler, resimler, kartpostallar, reklam filmleri, gazoz şişeleri, sinema biletleri, afişler, sigara izmaritleri, piknik sepetleri, takma eller gibi oldukça geniș bir yelpazede değerlendirilebilecek nesnelerle ve eșyalarla koruma altına almaya çalışır. Zihinlerde ne kadar kuvvetli yer tutarlarsa tutsunlar, anı sahiplerinin ölmesiyle, tam bir unutuluş içinde kaybolup gidecek aşklar, bağlllıklar, sevgililer, mutluluklar, hüzünler ve hepsi de tek tek değerli olan anlar, hatta Kemal'in bizatihi kendisi, onun takıntılı kişiliği ve gayretlerinin sonucunda Füsun'un Çukurcuma'daki iki katlı evinde bir müzeye sığınıp ebedileşirler.

\begin{abstract}
"Yaşadığımız bütün anlar içerisinde neden bu anı seçtiğimizi açıklamak da, kendi hikâyemizi bir roman gibi yeniden anlatmayı gerektirir elbette. Ama en mutlu anı işaret ettiğimizde, onun çoktan geçmişte kaldığını, bir daha gelmeyeceğini, bu yüzden bize acı verdiğini de biliriz. Bu acıyı dayanılabilir kılan tek şey, o altın andan kalma bir eşyaya sahip olmaktır. Mutlu anlardan geriye kalan eşyalar, o anların hatıralarını, renklerini, dokunma ve görme zevklerini bize o mutluluğu yaşatan kişilerden çok daha sadakatle saklarlar" (2014: 80)
\end{abstract}

Kemal, müzeyi kurarken bir roman yazılmasını da ister. Dış dünyadan ve yüksek sosyeteden kaçarak sığındığı Çukurcuma'daki evi bir müzeye dönüștürürken, romanı da bir katalog gibi kaleme aldırması gerektiğine karar verir: "Müzemin, içindeki bütün eşyaların hikâyelerinin tek tek ayrıntılı bir şekilde anlatıldığı bir katalogu olması gerektiğini o gece anladım. Bu da, elbette benim Füsun'a olan aşkımın ve ona hayranlığımın hikâyesi olacaktı" (2014: 529). Satır aralarında okuru ve "müzegezer"i aşkının peşinde bir yolculuğa çıkaran Kemal, mimar İhsan Bey aracıllğıyla yeniden düzenlediği bu binada bir tür rehberlik vazifesi üstlenir. "Eşyaların gücü, içlerinde birikmiş hatıralar kadar, bizim hayal ve hatırlama gücümüzün cilvelerine de bağlıdır elbette." (2014: 337) diyen Kemal, Füsun'a, içinde yetiştiği çevreye, anne-babasına, 70 'ler İstanbul'una atıfta bulunan hemen her nesneyi ilgi çemberinin içine alır. Bu nesnelere yüklediği kişisel anlamlar ve değerlerin başkalarınca paylaşılacağına emindir. Mutluluğunu sadece kendine saklamak istemez, hikâyesi ve müzesi aracılığılla bu mutluluğu paylaşmak ister: "Zaten romanın ve müzenin amacl, hatıralarımızı içtenlikle anlatıp mutluluğumuzu başkalarının mutluluğu haline getirmek değil midir?" (2014: 352).

Çukurcuma'ya gitmeden önce Merhamet Apartmanı'nda birikmeye başlayan nesneler, Kemal'in bu evi ziyaret ettiği sekiz yıl zarfında azalmadığı gibi artar. Karışık ve düzensiz çağrışımlarla hareket ederek topladığı nesneler, giderek Kemal'in zihninde bir anlam bütünlüğü kazanır:

“Çukurcuma'daki evdeki her şey, yavaş yavaş kafamdaki Füsun fikrinin bir parçası haline geliyordu. Haftada üç-dört kere Füsunu gördüğüm, görebildiğim için mutlu olduğum kadar. Keskinlerin evinden yani Füsun'un hayatından- üç-dört, bazan daha da çok altı-yedi, hatta en mutsuz zamanlarımda olduğu gibi on-on beş tane eşyayı alıp (çalmak yanlış kelime) Merhamet Apartmanına götürdüğüm için de bir

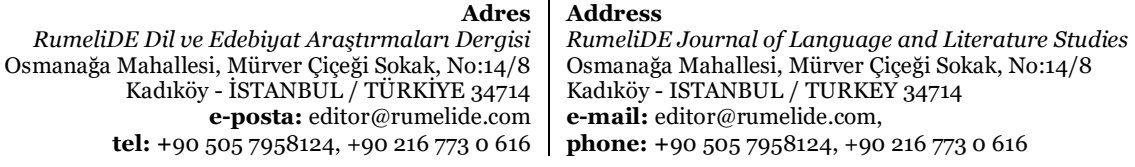


zafer duygusuna kapılırdım. Füsun un bir eşyasını, mesela televizyona dalgın dalgın bakarken elinde zarafetle tuttuğu bir tuzluğu kaşla göz arasında cebime indirmiş olmak, sohbet ederken, ağır ağır rakımı içerken tuzluğun cebimde olduğunu, "artık ona sahip olduğumu" bilmek bana öyle bir mutluluk verirdi ki, akşamın sonunda koltuğumdan çok fazla zorlanmadan kalkabilirdim" (2014: 389).

Toplanan her nesne, Kemal'in zihnindeki Füsun imgesini tamamlarken, okurun zihninde de Merhamet Apartmanı, Nişantaşı, Çukurcuma ve Masumiyet Müzesi eksenlerindeki Kemal imgesi yerli yerine oturur. Varlığı tamamen Füsun'la dolmuş olan Kemal, o öldükten sonra da aşkını yaşamaya, hatıralarını anmaya devam eder. Fakat Kemal, bu anışın geçmişle ilgili bir şey olduğunu anlamaya başladığında onu düşündüren ve üzen şeyin kendi acıklı durumu olduğunu da kavrar. Böylece müze kurma fikrini giderek benimseyen Kemal, yıllar boyunca dünyanın çeşitli ülkelerine seyahatler yapar. Bu seyahatlerde görüp beğendiği küçük müzelerden ilham alır. Bazısını defalarca ziyaret ettiği 5723 müzeyi gezer. Bu müze ziyaretleri onun kendini kapattığı iç âleminden dışarıya yönelişi, başka insanların hayatıyla temasa geçişidir ve bir bakıma Kemal'in olgunlaşma hikâyesinin basamakları olurlar (Parla, 2018b: 60). Evin müzeye dönüştürülmesi, eşyaların düzeni ve müze-evde yaşamaya devam edilmesi gibi hususlarda ilham aldığı müzelerden birkaçıysa şunlardır: Proust Müzesi, Gustave Moreau Müzesi, Frederic Mares Müzesi, Ava Gardner Müzesi, Edith Piaf Müzesi vb.

Kemal, seyahatlerine ara verdiği zamanlarda müzesinde kalmaya başlar. Sade bir yatak odası hâline getirilen çatı katı, onun yeni yuvası olur:

“Merhamet Apartmanında, üzerinde Füsun ile seviştiğimiz somyayı, küf kokulu şilteyi ve mavi çarşafı da bir müze olarak yeniden düzenlediğimiz binanın çatı arasına götürmüştüm. Keskinler bu evde yaşarken farelerin, örümceklerin, hamam böceklerinin dolaştı̆̆ı ve su deposunun durduğu karanlık, küflü çatı arası şimdi temiz, aydınlık ve yıldızlara bakan bir oda olmuştu" (2014: 527).

Çatı katının "yukarı”ya yani aşkın olana işaret ettiğine dikkat çeken Jale Parla, Kemal'in aynı zamanda hikâyesini, yazar Orhan Pamuk’a anlattığı bu sade odanın aşkın olana, yani sanata açılan bir imge olduğunu ifade eder. "Sanatın ulaşılmazlığı, görkemini çağrıştırmaktan çok uzak ama merhamet uyandıran bir oda"dır burası (2018a: 68). Mehtaplı bir gecede, çatıya açılan pencereden vuran ışı̆̆ın altında müzesini seyreden Kemal, giriştiği işin büyüklüğünü görüp şaşırır. Aynı zamanda hatıraların sinmiş olduğu mekânın ve eşyanın derinliği karşısında da ürperir:

\begin{abstract}
"Mehtaplı bir gece yarısı Çukurcuma'daki evde, çatı arasındaki küçük perdesiz odamda hoş bir ışığın içinde uyandım ve altımdaki büyük delikten müze boşluğuna, aşağıya baktım. Bazan hiç tamamlanmayacakmış gibi gelen küçük müzemin pencerelerinden, gümüş bir ay ışığı içeri vuruyor; boșluğu ve yapıyı, sanki sınırsız bir mekânmıș gibi korkutucu gösteriyordu. Her biri birer balkon gibi boşluğa uzanan alt katlarda, otuz yıldır biriktirdiğim bütün koleksiyonum gölgeler içinde duruyordu. Füsun'un ve Keskin ailesinin bu evde kullandığı eşyaları, Chevrolet'nin paslı enkazını, sobadan buzdolabına, üzerinde sekiz yıl akșam yemeği yediğimiz masadan seyrettiğimiz televizyona, her şeyi görebiliyor ve eşyaların ruhlarını fark eden bir Şaman üstadı gibi, onların hikâyelerinin içimde kıpırdandıklarını hissediyordum" (2014: 529)
\end{abstract}

Ay ışı̆̆ında seyrettiği müzesindeki eşyaların her biri bir ana ve anıya işaret etmektedir. Kemal, bu anları ve anıları tek bir çizgide birleştirmek için bir hikâyeye ihtiyacı olduğunu anlar. Bunun üzerine bir tür katalogroman yazdırmaya karar verir. Böylece eşyaların tek tek hikâyesi anlatılabilecektir. Kemal'in ev-müzesi, bir "nesneler belleği"ne dönüşür6.

Romanlarda basit bir dekor olmanın ötesine geçen, roman kişilerinin iç dünyasını yansıtan algısal mekânlarda "anlatı kişileri, mekâna kendi kimlik ve kișiliklerinden bir iz bırakarak mekânı sadece üzerinde yașanan bir yer değil bireysel ve toplumsal anlamda belleksel bir mekâna dönüştürür" (Şahin, 2017: 31). Şahin, buradan hareketle geçmişi, şimdiyi ve geleceği birbirine bağlayan algısal mekânların -Jan Assmann'a atıfla- birer “nesneler belleği” hâline geldiğini söyler (Şahin, 2017: 31). Assman'a

Adres | Address

RumeliDE Dil ve Edebiyat Araştırmaları Dergisi $\quad$ RumeliDE Journal of Language and Literature Studies Osmanağa Mahallesi, Mürver Çiçeği Sokak, No:14/8 Osmanağa Mahallesi, Mürver Çiçeği Sokak, No:14/8

Kadıköy - ÍSTANBUL / TÜRKIYE 34714 Kadıköy - ISTANBUL / TURKEY 34714 e-posta: editor@rumelide.com e-mail: editor@rumelide.com, tel: +90 505 7958124, +90 2167730616 phone: +90 505 7958124, +90 2167730616 
Çatıda gecelerken, sergilediği eşyalarla beraber uyumanın zevkini çıkaran Kemal, mimar İhsan Bey'in "binanın ortasında açtı̆̆ı büyük boşluk aracıllğıyla sadece mekânın ve eşyanın derinliğini değil, sevginin zamanı aşan boyutunu da deneyimler. Kemal'in ifadesiyle "Gerçek müzeler, Zamanın Mekân'a dönüştüğü yerlerdir" (2014: 528). İște bu bakımdan Masumiyet Müzesi bir kronotoptur. Yitik zamanın peşinde giden Proustvari bir zihin yolculuğunun sahnesidir. Walter Benjamin'in Proust için söyledikleri, Masumiyet Müzesi romanı için de geçerlidir: "Sınırsız zaman değildir Proust'un bize açtığı ebediyet, çizgileri kesişen sarmal zamandır. Asıl ilgilendiği, zamanın en gerçek — yani mekâna bağlı— geçiş biçimidir; ve bu geçiş de hiçbir yerde içteki hatırlama ve dıştaki yaşlanmada olduğu kadar belirgin değildir" (Benjamin, 2012: 111). Kemal'in ilerleyen yaşıyla birlikte, hatıralarının derinliği de artar. Zaman akıp giderken o, yakaladığı tek tek anlarda ölümsüzlüğü tadar. Müzenin girişinde, zemine resmedilmiş bulunan sarmalı da bu açıdan bir kez daha değerlendirmek mümkündür.

Bir Proust okuru olan ve Proust Müzesi'ni de gezen Kemal, eşyadan ve anlardan hareket ederek anılarına doğru yolculuk yapar. Romandaki 83 bölüme karşılık gelen 83 vitrin hazırlanır müzede. Bu, Bachelard'ın mekânın peteklerine sıkıștırılmış zaman imgesiyle de uyumlu bir yerleștirmedir. Kemal, yakaladığı anları vitrinlere hapseder ${ }^{7}$. Bunların hepsi de onun iç dünyasında yerli yerine oturmuş görüntülerdir. Kemal'in kendisi bir hafıza mekânıdır, zihninde birleștirdiği anların geniş bir zamana yayıldığı hissine kapılır. Kemal, "müzegezer"e de çizgisel zamanı unutturmak ister. Bunun için müzedeki koleksiyonun her bir parçasının, sergi alanının her yerinden görülmesini ister: "Hayatta en büyük teselli budur. Kalpten gelen dürtülerle yapılmış ve iyi kurulmuş şiirsel müzelerde, sevdiğimiz eski eşyalarla karşılaştığımız için değil, Zaman kaybolduğu için teselli oluruz" (2014: 537).

Bir müzenin gezmek için değil yaşamak için ziyaret edilmesi gerektiği düşüncesinde olan Kemal, romana bir bilet koydurmak suretiyle okuru müzesine, aşkını ve anlarda somutlaştırdığı mutluluğunu paylaşmaya davet eder.

Kemal Basmacı, romandaki kayıtlara göre 2007'de vefat eder. Masumiyet Müzesi romanı ise 2008'de yayımlanır. Yazar Orhan Pamuk, 2012'de Çukurcuma'da Masumiyet Müzesi'nin açılışını yapar. Böylelikle roman, gerçek hayata sızar ve kurmaca metin, gerçek bir kataloga dönüşür. Bununla birlikte roman yazarı da hem romanda anlatıcı olarak varlığını açık eder hem de romanını yazarken kendi çevresinden, hatıralarından ve yetiştiği atmosferden faydalanarak metnini kurar. Böylece yazarın ait olduğu gerçek hayat da romana sızmış olur.

\section{Sonuç}

Kurmaca metnin iki önemli unsuru olarak ortaya çıkan zaman ve mekân, bir anlatının zeminini teşkil eder. Romanın olay örgüsü ve kişiler dünyasıyla karşılıklı ilişki içinde olan zaman ve mekân unsurlarının birbiriyle de sıkı bir bağlantısı vardır. Bu bağlantıdan hareketle zaman ve mekân unsurlarının bir arada değerlendirilmesi gerektiğini savunan Mihail Bahtin, edebiyat eleştirisine "kronotop" kavramını getirir. Kelime karşıllı̆ı tam olarak "zaman-mekân" demek olan bu kavram zamanın ve mekânın birlikteliğine vurgu yapar. Kronotoplar bir anlatının temel yapıtaşıdır ve olay örgüsünün düğümlerini içerir. Romanda tespit

göre doğduğu andan itibaren çeșitli eșyalarla çevrili bulunan insan, bu eşyalarda hem kendi yansımasını hem geçmiş nesillerin izlerini görür. Çevresindeki varlıkların hatırlattığı bu farklı zaman dizinleri “nesneler belleği”ni oluşturur (Assmann, 2015: 27). Masumiyet Müzesi de böyle bir nesneler belleğine dönüşür. Kemal, ay ıșı̆̆ı̆ altında bu durumun farkına varır. Jale Parla'ya göre romandaki bölümlerle müzedeki vitrinlerin karşllıklı olarak yerleştirilmesindeki "montaj” fikri, müzenin ve romanın birbirini desteklemesini sağlamaktadır. Parla, "parçaların poetikası" olarak adlandırdığı yöntem sayesinde bu iki eserin birbirlerini var ederken ayrı ayrı da durabildiklerini söyler. Ona göre hayat kesintisiz bir şekilde durmaz zihnimizde: "Hayatımız en eski anılarımızdan bugüne tam olarak değil, bütün bir nehir olarak değil, kesik kesik parçalarıyla bizimdir; bir montajdır belleğimizde" (2018a: 66).

RumeliDE Dil ve Edebiyat Araştırmaları Dergisi Osmanağa Mahallesi, Mürver Çiçeği Sokak, No:14/8 Kadıköy - ISTANBUL / TÜRKIYE 34714 e-posta: editor@rumelide.com tel: +90 $5057958124,+902167730616$
Address

RumeliDE Journal of Language and Literature Studies

Osmanağa Mahallesi, Mürver Çiçeği Sokak, No:14/8

Kadıköy - ISTANBUL / TURKEY 34714

e-mail: editor@rumelide.com

phone: +90 505 7958124, +90 2167730616 
edilecek her kronotop belirli bir duygu ve değer yükü taşır ve anlatı dünyasında zamanı somutlaştırırken mekâna da derinlik katar. Bahtin, çeşitli incelemelerinde yol-karşılaşma, şato, taşra kasabası, eşik, salon gibi kronotoplar belirler. Bununa birlikte her eserin içinde bulunabilecek sınırsız sayıda kronotopun varlığına da dikkat çeker.

Orhan Pamuk'un 2008 yılında yayımlanan romanı Masumiyet Müzesi, hem modern hem postmodern özellikler taşıyan bir aşk, arayış ve bellek romanıdır. Romanın hatırlamayla ilişkisi ve başkişi Kemal Basmacı'nın psikolojik gerçekliği yoluyla mekâna ve zamana dair getirilen yorumlar, esere kronotoplar çerçevesinden yaklaşılabileceğini gösterir.

Romanın büyük bir bölümünde anlatıcllğı üstlenen Kemal Basmacı tarafından muhataplarının dikkatine sunulan şehir (İstanbul), yol, ev (Teşvikiye, Çukurcuma, Anadoluhisarı), eşik, kapı, pencere-balkon, sandıkdolap-çekmece ve müze kronotopları romanı psikolojik ve toplumsal bir derinlikle kavramayı sağlar.

Tutkulu bir aşka sahne olan İstanbul, romanda 70’ler Türkiye'sine bir pencere açılmasını da sağlar. Nişantaşı, Fatih, Çukurcuma ve Beyoğlu gibi İstanbul'un birbirinden farklı toplumsal kimliklere ev sahipliği yapan semtleri arasında mekik dokuyan roman kahramanı sayesinde, okur aşk, sınıf farkı, toplumsal aidiyet, modernlik ve geleneksellik gibi kavramları da yeniden düşünür.

Masumiyet Müzesi'nde, başlı başına bir kozmos olan evin taşıdığı anlam da çeşitli açılardan değerlendirilir. Toplumsal ve ekonomik farklılıklar, evlerin yapısını ve dekorunu değiştirir. Bununla birlikte evi kıymetlendiren asıl unsur duvarlarına, eşyasına sinen zamanın kokusu ve hatıralardır. Romanda yer alan evler, hatıralarla yüklüdür. Acı, tatlı olaylara sahne olan evler, roman kişilerinin sığınağı olduğu kadar, bir dönüşüm mekânı yani kozasıdır.

Evlerin odaları, eşikleri ve kapıları ise anlık kararların yeridir. Roman boyunca sınırların ihlal veya iptal edilişini bu kronotoplar üzerinden okumak mümkündür. Roman kahramanları insanlık için küçük, fakat kendileri için büyük adımları buralarda atar ve değişmeye başlarlar. Evin dışarıyla irtibatını sağlayan pencere ve balkonları da Masumiyet Müzesi'nde kronotop olarak değerlendirilir. Kahramanların kısa bir süre geçirdiği bu yerlerde hissettikleri duygular, psikolojik zamanın varlığını ve derinliğini ortaya koyar.

Evler büyük mahremiyet bölgeleriyken, sandık veya dolaplar da ev içindeki daha küçük, daha kişisel mahremiyet bölgeleridir. Masumiyet Müzesi kişileri bu eşyaların içine gizli yaşamlarını, hatıralarını koyup saklar. Bunlar küpe, tarak, toka, çorap, takma diş gibi nesneler, mektuplar olabilir. Dolapları ve çekmeceleri karıştıran roman kişileri, bunlar aracılığıyla zamanda bir yolculuğa çıkar ve hatıralara dalar.

Bu hatırlama romanında Kemal Basmacı'nın ikinci evi, mabedi olan Masumiyet Müzesi de içinde solunan ruhla ve sergilenen dönem eşyalarıyla bir kronotoptur. Müze, hem gerçek hem kurgudur; hem geçmişi hem geleceği kucaklar; hem kişisel hem toplumsaldır. Masumiyetin ve onu ortadan kaldıran deneyimin mekânı olan müze, ziyaretçisine zamansızlık hissi yaşatır.

Romanda tespit edilen kronotopların her biri zamanın mekânlaşmasına iyi birer örnek teşkil eder. Bu kronotoplar sayesinde roman kişilerinin yapıp etikleriyle kendilerini ve çevrelerini değiștirmesi, dönüştürmesi etkili bir şekilde ortaya konmuş olur. Kronotoplar, Masumiyet Müzesi'nin anlam dünyasını derinleștirir ve zenginleştirir. Taşıdıkları duygu ve değerlerle okur için zengin bir çağrışım dünyasına kapı aralar.

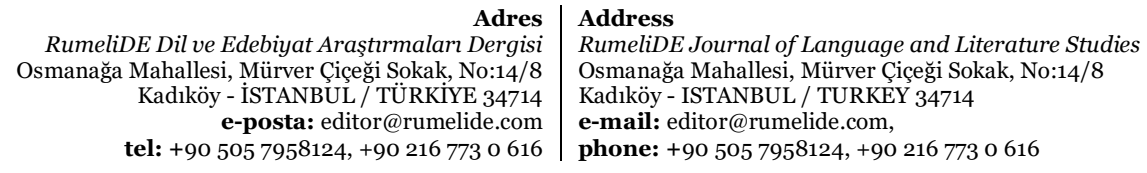


Buradan hareketle, aslında romanın kendisinin de bir kronotopa dönüştügünü söylemek mümkündür. Edebî dile yerleșerek ebediliğin kapısını açmak isteyen anlatıcı ve yazar, metni farklı kimliklerin, kişisel ve toplumsal değer yargılarının, sınıflar arası ve siyasi nitelikli çatışmaların kaynaştı̆̆ı ve hepsinin üzerinde de âlemi dolduran yoğunluğuyla aşk duygusunun yer aldığı bir kronotop hâline getirir.

\section{Kaynakça}

Aktaş, Ş. (1991). Roman sanatı ve roman incelemesine giriş. (2. bs). Ankara: Akçağ.

Assmann, J. (2015). Kültürel bellek-eski yüksek kültürlerde yazı, hatırlama ve politik kimlik. (çev. Ayșe Tekin). (2. bs.). İstanbul: Ayrıntı.

Bachelard, G. (1996). Mekânın poetikası. (çev. Aykut Derman). İstanbul: Kesit.

Bahtin, M. (2004). Dostoyevski poetikasının sorunları. (çev. Cem Soydemir). İstanbul: Metis.

Bahtin, M. (2014). Karnavaldan romana edebiyat teorisinden dil felsefesine seçme yazılar. (der. Sibel Irzık, çev. Cem Soydemir). (2. bs.). İstanbul: Ayrıntı.

Benjamin, W. (2012). Proust imgesi. Son bakışta aşk. (haz. Nurdan Gürbilek, çev. Orhan Koçak). Metis.

Bourneur R. ve Quellet R. (1989). Roman dünyası ve incelemesi. (çev. Hüseyin Gümüş). Ankara: Kültür Bakanlığı.

Chatman, S. (2008). Öykü ve söylem-filmde ve kurmacada anlatı yapısı. (çev. Özgür Yaren). Ankara: De Ki.

Demir, A. (2011). Mekânın hikâyesi-hikâyenin mekânı. İstanbul: Kesit.

Elçi, H. İ. (2003). Roman ve mekân-Türk romanında ev. İstanbul: Arma.

Esen, N. (2012a). Ahmet Mithat'ta kronotop kavramı. Modern Türk edebiyatı üzerine okumalar. (2. bs). İstanbul: İletişim. ss. 69-73.

Esen, N. (2012b). Orhan Pamuk'un romanlarında anlatım çeşitliliği. Modern Türk edebiyatı üzerine okumalar. (2. bs). İstanbul: İletişim. ss. 215-222.

Irzık, S. (2014). Önsöz. Karnavaldan romana edebiyat teorisinden dil felsefesine seçme yazılar. (der. Sibel Irzık, çev. Cem Soydemir). (2. bs.). İstanbul: Ayrıntı. ss. 9-32.

Jahn, M. (2012). Anlatıbilim. (çev. Bahar Dervişcemaloğlu). İstanbul: Dergâh.

Lukacs, G. (2003). Roman kuramı. (çev. Cem Soydemir). İstanbul: Metis.

Paliçko, E. (2020). Bir deneyim olarak edebiyat. Akademik dil ve edebiyat dergisi. 4 (1), 116-130. DOI: 10.34083/akaded.687847.

Pamuk, O. (2014). Masumiyet Müzesi. (4. bs.). İstanbul: YKY.

Pamuk, O. (2020). Banu Güven ile Masumiyet Müzesi röportajı. Manzaradan parçalar-hayat, sokak, edebiyat. (3. bs.). İstanbul: YKY.

Parla, J. (2012). Don Kişot'tan bugüne roman. (11. bs). İstanbul: İletişim.

Parla, J. (2018a). Kapalılık, kapanma, kapatılma hakkında bir roman: Masumiyet Müzesi. Orhan Pamuk'ta yazıyla kefaret. İstanbul: YKY. ss. 51-56.

Parla, J. (2018b). Masumiyet, müze, merhamet: Masumiyet Müzesi ve Masumiyet Müzesi. Orhan Pamuk'ta yazıyla kefaret. İstanbul: YKY. ss. 57-68.

Şahin, V. (2017). Halid Ziya Uşaklıgil'in 'Așk-ı Memnu' romanında mekân-insan diyalektiği. Romanda mekânromanda mekân poetiği ve çözümlemeler. (ed. Ramazan Korkmaz, Veysel Şahin). Ankara: Akçă̆ Yayınları. ss. 27-46.

Tekin, M. (2001). Roman sanatı 1 (romanın unsurları). İstanbul: Ötüken Neşriyat.

Wellek, R. ve Warren, A. (1983). Edebiyat biliminin temelleri. (çev. Ahmet Edip Uysal). Ankara: Kültür ve Turizm Bakanlığı.

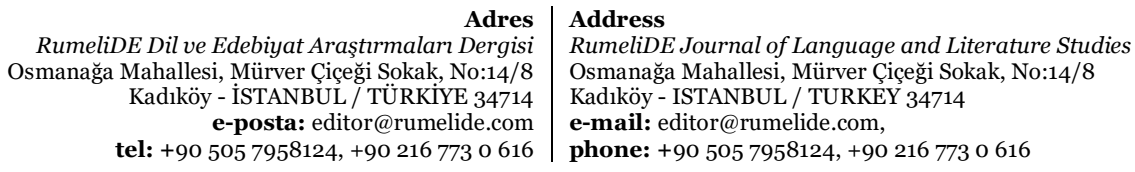

